\title{
Privatization and Financial Markets in European Union: A Social Welfare Perspective
}

\author{
Ioannis N. Kallianiotis \\ University of Scranton, \\ USA
}

\section{Introduction}

Since 1980, with pressure from IMF and lately, from the EU and the Troika, privatization has become the key dimension of the world capital markets and European Union has been the international leader in selling state-owned productive assets (national wealth) to the private sector (mostly to foreign firms). This trend started because the states have historically taken a major direct role in the economy of all European countries [Kallianiotis (2007)], due to security, social policy, control of the enterprises, ownership of the national assets (wealth) by the nation, avoidance of private monopolies, and prevention of social inequality. During the Great Depression (early 1930s), many productive assets were shifted to state ownership, as failing enterprises were taken over by governments in the Western Europe. ${ }^{1}$ In the Eastern Europe, due to the socialist system, all enterprises ended up in the hands of the government. The last major expansion of state control in Western Europe was the nationalization of the banks in France at the outset of the Mitterrand administration in 1981. [Walter and Smith (2000, p. 165). But since that time the trend has changed and privatization is considered the only way of business, independently of the social cost to the country. On Sunday, September 7, 2008, the U.S. Treasury Secretary, Henry Paulson, announced plans to take control of troubled mortgage giants Fannie Mae and Freddie Mac, replaced the companies' chief executives and provided up to $\$ 200$ billion in capital to restore the firms to financial health. This nationalization movement had a positive effect, with stock markets rallying in the U.S. (DJIA gained 289.78 points or $2.6 \%$ to $11,510.74$ ) and abroad, and mortgage rates fell. Also, Germany took a $25 \%$ stake in Commerzbank after injecting another $\$ 13.63$ billion to shore up its finances. Further, Lloyds Banking could be pushed closer to nationalization, if the U.K. economy continues to sour. We see in many cases that governments must be in control of industries and firms for the benefits of the citizens. The uncontrolled private firms will cause serious problems in the future of our economic and social lives and due to globalization the (domino) effect will move to allover the world. Nationalization of some most deeply wounded financial institutions, during the 2008 financial crisis, might be the best policy to save the economies and bring back stability and

\footnotetext{
1 The Great Panic or "planned" financial crisis (late 2000s) led governments to similar actions, but at a smaller scale. See, Kallianiotis (2011c).
} 
confidence. Merkel's Cabinet, on February 18, 2009, approved draft legislation allowing the state to take over lender Hypo Real Estate Holding AG, paving the way for the first German bank nationalization since the 1930s. The bill, which was put to parliament on April 3, let the government carrying out compulsory purchases of shares in "systemically relevant" banks. The U.K. classified two bailed-out banks (Royal Bank of Scotland Group PLC and Lloyds Banking Group PLC) as public-sector entities, moving up to $\$ 2.136$ trillion of liabilities to its balance sheet. Lately, President Hugo Chavez said on August 17, 2011 that he planned to nationalize Venezuela's gold-mining industry in an attempt to boost international reserves. ${ }^{2}$

Also, Royal Bank of Scotland received billions of pounds from U.K. government, in a rescue deal that could be a model for other banks, but left RBS nearly nationalized. On the one hand, U.K. Prime Minister, Gordon Brown, decided to nationalize troubled mortgage lender Northern Rock Bank, which had racked up more than $\$ 48.7$ billion in debts to the state. Later, U.K. nationalized mortgage lender Bradford \& Bingley. Latvia took a 51\% stake in its largest locally owned bank amid concerns about Parex's ability to repay two syndicated loans. On the other hand, many states in the U.S. were planning to lease major toll roads under an arrangement known as public-private partnerships; investors lease or buy roads, bridges or other infrastructure, operate them independently and collect tolls.

The French government was considering injecting as much as $€ 4$ billion ( $\$ 5.1$ billion) and taking a stake of about $20 \%$ in a new mutual bank to be formed by the planned merger of Groupe Banque Populaire and Groupe Caisse d' Epargne. Also, Citigroup was in talks with federal officials about the U.S. taking greater ownership of the bank by converting its $7.8 \%$ stake of preferred shares to as much as $40 \%$ of Citigroup's common stock. Doing so gave the wobbling bank a desperately needed boost to its capital, but less control of its destiny. In 2008, during the past five quarters the bank had $\$ 28$ billion in losses. Federal Reserve Chairman Ben S. Bernanke said, while the U.S. government might take "substantial" stakes in Citigroup Inc. and other banks, it did not plan a full-scale nationalization that could wipe out stockholders. Nationalization is when the government "seizes" a company, "zeroes out the shareholders and begins to manage and run the bank, and we don't plan anything like that," Bernanke told lawmakers in Washington on February 25, 2009.

Thus, even the free-market oriented U.S. was thinking about nationalization. Senate Banking Committee Chairman Christopher Dodd said, banks may have to be nationalized for "a short time" to help lenders including Citigroup Inc. and Bank of America Corp. survived the worst economic slump in 75 years. The DJIA fell another 100.28 points $(-1.3 \%)$ to $7,365.67$, flirting with a 12-year low because the White House was preparing to nationalize several large U.S. banks. Gold topped $\$ 1,000$ /ounce as investors sought a refuge. At the same time, a stimulus provision was discouraging banks that received federal bailouts from hiring skilled foreign workers, which was a very good labor policy for the country. This was and continues to be absolutely necessary to improve employment in the U.S. and control a little the Asian "invasion", which has diluted the traditional values of the country, and to keep the salaries at a survival level for American citizens and stimulate American children to study for improving their income. The country as well as EU member-nations need

2 Chavez has already nationalized banks, telecommunications, oil fields, the power sector, and hundreds of thousands of acres of farmland. Venezuela produces about 1.7 metric tons of gold a year. See, The Wall Street Journal, August 18, 2011, pp. A1 and A10. 
desperately a domestic policy, which would improve social welfare of their citizens; these past liberal policies have destroyed the countries and have made them as third-world nations. These fears for possible nationalizations were provisional, due to the financial crisis. Lately, Belgium nationalized part of Dexia Bank for $\$ 5.4$ billion. Also, Greece activated rescue fund for Proton Bank.

Unfortunately, the last 30 years, privatization has become the only trend, even though that has been economically and politically disruptive. "More than 80 countries have launched ambitious efforts to privatize their state-owned enterprises. Since 1980, more than 2,000 state-owned enterprises (SOEs) have been privatized in developing countries, 6,800 worldwide." [Kikeri, Nellis, and Shirley (1992)]. The total value of world wide privatizations exceeded $\$ 185$ billion by 1990 and the privatizations only in Europe and Central Asia between 1990 and 2006 exceeded \$207 billion. [Private Participation in Infrastructure Database, The World Bank Group.] Governments, especially those in Euro-zone that are in debt crisis, want revenue and they are selling any assets that the country had accumulated; but, there is another reason, too, public workers, acting unethically, have reduced their productivity close to zero. This sale-off tension is a short-term objective of most privatization programs; revenue collection for the current government and the pressure from the EMU, ECB, and IMF (Troika) to reduce budget deficits and subsidies. Also, the liberalization policies, the deregulation, and the globalization of the financial system, lately, try to increase supply and demand of securities in the domestic capital markets and integrate them with the EU and the international one; therefore, privatization is considered as the main contributor of financial assets.

In the early 1980s, the states accounted directly and indirectly for half of GDP in the European economies. However, as a result of these privatizations, the share of state-owned enterprises in the GDP of OECD countries declined from 10\% in the mid-1970s to about 7\% in the late 1980s and 5\% at the end of the 1990s. Governments raised almost $\$ 670$ billion by direct sales and public share offerings between 1977 and 1998; they covered some of their tremendous budget deficits and contributed to the liquidity of the financial market. In the OECD countries, during the 1990s, primary and secondary privatization share offerings accounted for more than 55\% of all equity offerings in Europe, and in countries such as Italy and Spain, they accounted for more than 70\% of stock market capitalization by 1998 . [OECD, Privatization Trends, Paris, 1999]. The purpose, here, is to examine this vague "intellectual" debate, which is very common in EU, about the privatization and its effect on financial markets and about the kinds of activities that belong in the public sector and the private one. The role of an uncorrupted government is important to be emphasized, too. Even, Czech President Klaus assailed the EU as undemocratic and said it should halt further centralization of powers. Troika is forcing Greece to sell public enterprises and derive $€ 50$ billion from these sales; otherwise, there will be restrictions on the $6^{\text {th }}$ installment of the $€ 110$ billion loan that had been approved in 2010. [Kallianiotis (2011a)].

Undoubtedly, the focus, here, is on privatization in the members of the EU and the Eurozone countries. During 1990s, the EU accounted for $\$ 301$ billion in privatization proceeds. [Walter and Smith (2000, p. 172).] Walter and Smith (2000, Figure 6.2, p. 174) give a breakdown by country of almost every privatization activity. European privatization after World War II began in Germany under the Adenauer government, with the 1961 sale of the state's majority stake in Volkswagen to the public. Placement of shares with small investors 
was also emphasized. This was followed in 1965 with the sale of Veba. Later, the first massive privatization program in Britain was launched by the government of Margaret Thatcher, which redefined the role of the state and the private firm in economic activities. The first major transaction was that of British Telecom in 1984, followed by massive privatizations of British Airways, British Petroleum, British Airports Authority (BAA), British Rail, Cable \& Wireless, and British Aerospace. All involved share sales to institutional and retail shareholders in the U.K. and abroad; it reduced the proportion of state own enterprises in the U.K. economy from over 10\% of GDP in 1978 to virtually zero, when the Conservatives left office in 1997, and certainly, it increased the number of firms listed in the stock exchanges. The Labour party shifted its position from bitter opposition to privatization and threats of re-nationalizations in the early days of the Thatcher initiative to strong support by the time the Blair administration took office. Amazing homogeneity (sic) in all European parties (conservatives, socialists, and communists) in power in EU, today!

More recent, France embarked on an ambitious program of privatization under the government of Prime Minister Jacques Chirac in 1986, which saw the privatization of 22 companies worth $\$ 12$ billion in the following two years, a process that was halted (but not reversed) by the socialists in 1988. Privatization was resumed by the Balladur government in 1993 and continued under the Jospin government, often with spectacular successes such as the $\$ 7.1$ billion France Telecom initial public offerings (IPO) in 1997. French privatization proceeds averaged over $\$ 7$ billion annually during 1994-1998, almost twice the amount in Germany during this period. Walter and Smith (2000, p. 174) show, in their Figure 6.2, Spain and Portugal, which undertook privatizations in 1997 and 1998, and Italy engaging in stateowned enterprises (SOE) sales of well over $\$ 60$ billion during 1994-1998. The Nordic countries and Greece, on the other hand, lagged a little behind much of the rest of Europe, but the last 30 years the socialists (PASOK) and the "centrists" (N.D.) in Greece are selling almost everything. In terms of industries, the most intense activity was in the telecommunications, financial services, transport, and public utilities sectors. The Maastricht treaty provides (imposes) a unique "motivation" for privatization in the entire EU.

Actually, the EU share of global privatizations has increased steadily as Commission directives have mandated market liberalization and reductions in subsidies and as the Maastricht fiscal targets have placed tremendous pressure on raising government revenues and limiting its spending, even now, during the current financial crisis, deep recession, and enormous unemployment, which require exactly the opposite policy. During 1998 alone, Italy undertook a public issue of BNL (Banca Nazionale del Lavoro) shares for \$4.6 billion, as well as the fourth tranche of privatization of ENI (Ente Nazionale Industiale, a major Italian industrial holding company) begun in 1995. France did a $\$ 7$ billion secondary offering of France Telecom shares, in addition to the sale of $2 \%$ to Deutsche Telekom to cement a strategic alliance between them. There were also insurance and banking offerings such as those by CNP Assurances and GAN. Spain raised over \$24 billion in privatization revenue in 1997 and 1998 through sales of shares in telecoms, Argentaria Bank, the Endesa power group and Tabacalera, the tobacco company. Portugal undertook secondary offerings of EDP electricity, BRISA, the motorway toll operator, and Cimpor cement companies. Finland sold a $22.2 \%$ stake in Sonara telecoms and a $15 \%$ stake in Fortum, the electricity company. Austria attempted its largest privatization in the form of a $25 \%$ share offer in Telekom Audtria for $\$ 2.33$ billion. Walter and Smith (2000, p. 178, Figure 6.4) depict the 1998 market value, sales, and profits of the 34 largest publicly-traded privatized companies in 
EU, each having a market capitalization of at least $\$ 15$ billion. Currently, with the pressure from Troika, Greece has to privatize SOEs to collect $€ 50$ billion, but the market is at a very bad financial distress (undervalued). Then, the Greek SOEs will be sold at a very low price (fire sales), which means negligible revenue for the government. ${ }^{3}$

Between 1991 and 2006, Greece has implemented 61 transactions worth over \$20 billion of privatization revenues. Privatization in Greece began in the early 1990s after the first election of the New Democracy Party. The government considered privatization as the main policy objective, and issued a list of firms to be privatized. The initial stage of the Greek privatization program mainly involved the enterprises belonging to the IRO. [OECD Economic Surveys, Greece, 1998, Public Enterprise Reform, Table 21, p. 111]. The first transactions date back to 1991 and 1992 with the full sales of the Olympic Marine shipping company, the Bank of Chios, and of Elvim (Heracles Gen Cement). However, the implementation of this first wave of privatizations was blocked by strong political and labor union opposition. The context changed after 1995, when Greece was admitted to candidacy in the European Economic and Monetary Union (EMU). This exerted pressure on the governments to implement structural reforms in order to foster policy credibility. Indeed, after a break lasting three years, the divestment process resumed in 1996 and gathered momentum through the second half of the 1990s onwards. During this second stage, which continues to the present, privatizations mainly involved the public utilities, services, and telecommunications.

In March 1996 telecommunications started being privatized with the initial public offer of Hellenic Telecommunications Organisation (OTE), with an offer of $7.6 \%$ of its shares. Subsequent sales of the telecommunication group occurred in 1997 (12.4\% of capital sold), in 1998 through two tranches of 3.5\% and 15\% of capital, respectively, in 1999, in 2002 and 2005. To date $70.6 \%$ of its capital has been sold, raising over $\$ 5.6$ billion. Other more recent transactions include the sale of $16 \%$ of the National Bank of Greece, which happened between 1998 and 1999. Then, the three subsequent issues of the state power producer Public Power Corporation (PPC, $\triangle \mathrm{EH}$ ), took place, respectively in 2001, 2002, 2003, and 2005 and worth overall about $\$ 1.4$ billion. In addition, the four tranches of the Greek Organization of Football Prognostics (OPAP) in 2001, 2002, 2003 and 2005, worth in total $\$ 2.75$ billion. The most proceeds were raised from the privatization of telecommunications (41\% of total revenues) and services of public utility (21\% of total revenues), such as water supply (i.e. the privatization of the Water Supply \& Sewerage System in 1999); electric, gas, and water distribution (i.e. the sale of the Gas supply company of Thessaloniki EPA - Thessaloniki in 2000); and the already mentioned electricity sector [i.e. Public Power Corporation (PPC)].

Also, the financial sector has raised $16 \%$ of total revenues. Among the commercial banks, investment banks, and holding companies privatized are: the Bank of Chios in 1991, the Bank of Athens in 1993, the Athens Bourse in 1997, the General Hellenic Bank in 1998 and 2004, the National Bank of Greece in 1998, 1999, 2003 and 2004, the Hellenic Industrial Development Bank in 1999, the Greek Stock Exchange Holdings in 2000, and finally the Agricultural Bank of Greece in 2000. Further, privatization of the state-owned enterprises (SOEs) was one of the goals of the Kostas Karamanlis' Government. In his Platform Speech (March 2004), he said that "Government will reduce its business activities, give up its role as a contractor and enhance its regulatory powers. At all events, it will maintain control on the

${ }^{3}$ See, George Delastic, “On Extreme Economic Betrayal”, Christian Vivliografia, August 27, 2011. 
natural monopolies of transport networks". The first move was the sell off in 2004 of an $8.2 \%$ stake in Hellenic Petroleum for around \$240 million. DEKA, the Greek state portfolio management agency, sold its stake to a unit of the Latsis Group. In November 2004, a 7.46\% stake in National Bank of Greece was placed with foreign and Greek institutional investors via an accelerated book-building process. Revenues were worth around $\$ 725$ million.

Furthermore, the goal of reducing budget deficit led the Government to plan an ambitious privatization program for 2005; it aimed to raise more than $\$ 2$ billion in the year. In this context, in July 2005, a $16.4 \%$ of the gambling company OPAP was sold via a retail and institutional public offer, raising more than $\$ 1.5$ billion. In September 2005, a $10 \%$ stake of the telecommunications company OTE was sold, via a public offer, generating revenues worth over $\$ 1$ billion. The privatization process continued in 2006 with the IPO of Postal Savings Bank, whose 35\% was sold on the Athens Stock Exchange for barely $\$ 800$ million. The largest privatization, ever occurred in Greece, took place in the second half of 2006, with the complete sale off of Emporiki Bank. The government sold to Crédit Agricole its 35.56\% stake, raising around $\$ 2.2$ billion. Another important operation is the public offer of Hellenic Telecom Organization (OTE). In June 2007, the government, finally, sold a 10.07\% stake for almost $\$ 1.5$ billion, as part of its ambitious privatization programme for the year, aimed at repaying the Country's public debt. After few days, in July 2007, the Greek government has completed another long-awaited operation: the sale of a $20 \%$ stake in Greek Postal Savings Bank for more than $€ 500$ million. With this operation, the Greek government once again, after the gratifying result of 2006 , has reached its privatization revenues target, $€ 1.7$ billion, well in advance than year end. ${ }^{4}$

After these privatizations, Deutsche Telekom AG gained control of Greece's phone company (Hellenic Telecommunications Organization, OTE), which created a goliath in the Balkans. The German telecommunications company paid about $€ 2.9$ billion ( $\$ 4.6$ billion) for $25 \%$ of the shares of OTE and in 2011 it took the majority control of the company. At the same time, OTE and Cosmote brought Deutsche Telekom access to Greece, Albania, Skopje, Serbia, Romania, and Bulgaria. In 2000, Deutsche Telekom acquired a majority stake in Hungary's Magyar Telekom Telecommunications that gave it indirect control of telecom companies in Skopje and Montenegro. In 2001, Deutsche Telekom acquired a direct majority state in Croatia's Hrvatski Telekom. We have created a private monopolist in Balkans and the workers and customers in these countries will be negatively affected. This is also a very serious problem for the security of Greece, which is surrounded by so many enemies.

Lately, Electricite de France SA submitted a bid for British Energy Group PLC, making it the frontrunner to buy the U.K. nuclear-power-plant operator, which was valued at $£ 7.25$ billion ( $\$ 14.16$ billion). This British utility company was 35\%-owned by the U.K. government and was put up for sale in March 2008. Other companies that were expected to submit some kind of offer for this British Energy included Germany's RWE AG and Spain's Iberdrola SA. Also, France Telecom SA made a $\$ 42$ billion takeover offer for TeliaSonera AB, the Swedish phone company, but TeliaSonera rejected France Telecom's cash-and-stock offer. Deutsche Bank reached a deal to buy a nearly 30\% stake in Deutsche Post's banking unit for $\$ 3.89$ billion. In March 2009, the Greek government succeeded to privatize the Greek airline carrier Olympic

${ }^{4}$ See, Privatization Barometer,

http:/ / www.privatizationbarometer.net/atlas.php?id=13\&mn=PM\&print=1 
Airways by selling it to Marfin Egnatia (MIG) for $€ 177.2$ million. In a few days European Commission (EU) gave the approval of this privatization and the ratification took place from the Privatization Committee of the Greek government. The new owner, Andreas Vgenopoulos, said that he will spend $€ 100$ million to buy new airplanes and was thinking to collaborate with Iberia, he kept the existing personnel of the carrier and he started accepting applications for new hiring of employees. Also, Russian oil firm Surgut bought a $21 \%$ stake in Hungarian national energy company MOL for $\$ 1.9$ billion. But, Chicago canceled a deal to privatize Midway airport after the winning consortium failed to line up funding.

Privatization has been imposed by some (neo-liberal entities), who believe that it might increase efficiency of the public sector, but it has contributed further to the weakening of the public sector, since public assets have been sold at very low prices that did not even compensate for the loss of future revenue from these companies. Alexiou (2003, p. 26) says that, "the contractionary nature of the policies imposed upon the EU member states, to arguably facilitate their transition into the monetary union appear to, at least in the short run, have created an economic environment that is far from conducive to employment creation. Lack of strategies that target real, rather than nominal variables, permeates current economic policy as this is run by the think-tanks of an independent European Central Bank and its affiliated institutions." Studies by Kay and Thompson (1986) and Wortzel and Wortzel (1989) suggested that privatizations did not promote economic efficiency, only governments have raised significant revenues through the sale of SOEs. Sappington and Stiglitz (1987) addressed issues related to state versus private ownership and they favored state ownership, together with many other studies. Bhaskar and Khan (1995) in a study of the Jute industry in Bangladesh found that privatization had a large and significant negative effect on the employment of white-collar workers, while the reduction in output is not statistically significant. Parker (1999) reviews privatization in each of the member states of the EU, identifies the differences in the levels of privatization activity, and explains that privatization may not lead to efficiency, but to redistribution of income and economic power. Morgen (2001) says that devolution and privatization have marked the neoliberal agenda of downsizing the state and minimizing its role in regulating and ameliorating the operation of the market. Becker (2007) deals with privatization of water and waste public firms in EU and does not expect full privatization of these monopolistic companies. Editors Freixas, Hartmann, and Mayer (2008) provide a variety of articles on developments in European financial markets and institutions and some of them are referred to privatization [i.e., Degeorge and Maug (2008, pp. 223-224)]. Luechinger, Meier, and Stutzer (2008) say that high general unemployment reduces individual welfare even for people who are still employed and the public sector attracts more risk-averse individuals than does the private sector. Kallianiotis (2009) says that the vast privatizations have caused huge social welfare losses. Kallianiotis and Dragone (2009) said that privatization in EU has become the only trend the last years, even though that has been economically and political disruptive. Then, excess privatization causes serious social welfare problems to our societies.

\section{Privatization, denationalization, individuals' utility, and social welfare}

\subsection{Preamble}

The term "privatization" has been introduced in 1930s and denotes the process of transferring ownership of state-owned enterprises (SOEs) from the public sector (government) to the 
private sector (business) making those private-owned enterprises (POEs). This can involve the denationalization of this enterprise or industry as well as allowing the private sector to provide what had been considered government (public) services. Privatization, then, refers to transfer not only the assets, but also any government function to the private sector including governmental functions like, revenue collection, law enforcement, and others. Also, privatization has been used to describe the buyout of the majority or all shares of a public corporation; privatizing a publicly traded stock. Investors, who will invest in these securities, will have an increase in their utility, but the effect on social welfare is questionable.

Privatization can take place through selling of shares on the stock market, share issue privatization (SIP) or by selling the entire enterprise or part of it to a strategic investor through the auction process, asset sale privatization (ASP) or the shares of ownership are distributed to all citizens (free or at a very low price), voucher privatization (VP). The SIP type is the most common and can broaden and deepen domestic capital markets, increase investment opportunities, and potentially economic growth, but there is risk involved, too. It can be difficult to find enough buyers, so prices can be low (or underpriced, due to financial crisis), capital gains and government revenue insignificant, and transaction costs very high. ASP is more common in developing countries and VP has mainly been used in the former socialist economies during their transition (Poland, the Czech Republic, Slovakia, and Russia). Share or asset sale privatizations are more beneficial to the government because bidders compete and offer higher price, which create more revenue for the government, if the financial assets are overvalued. Voucher privatizations create a sense of participation and inclusion of all citizens. There were many privatizations the last years (more than 1,800 transactions from 2000-2008) in EU, ${ }^{5}$ as Kallianiotis (2011e, Table 1 in Appendix) shows and these phenomena will continue until they will sell every asset, which belong to the public (citizens). Greece is forced by Troika to generate $€ 50$ billion from selling off every public enterprise and public real assets (structures and land, even archaeological monuments). In addition, Table 2 (in the same Appendix) gives the investment in projects of four different sectors (Energy, Telecom, Transport, and Water and Sewerage) from 1990 to 2006, which reached a total of $\$ 206.521$ billion. Further, data and their analysis are very important to make some inferences for the effects of privatization. Table 3 (in Appendix) depicts the 1998 market value, sales and profits of the largest publicly-traded privatized companies in Europe and Table 4 (in Appendix) ${ }^{6}$ shows the largest share offerings. Privatization slowed as the global financial crisis took hold and as political difficulties continued. But, at the same time, some nationalizations were expected in the wake of the crisis. Preliminary results for 2009 show a slight uptick in privatization value, as markets began to stabilize and as growing budget deficits led to new pressures for privatizations. ["Privatization Trends", View Point, Public Policy for the Private Sector, The World Bank, May 2010].

\footnotetext{
${ }^{5}$ Also, Kallianiotis (2011e, Table 8 in the Appendix) reveals the privatizations in EU from 1989 to 1999 and Table 9 from 2000-2008. See, http://rru.worldbank.org/Privatization/QueryDetails.aspx. The Europe \& Central Asia (ECA) region raised over $\$ 171$ billion from privatizations between 2000 and 2008 , representing $38 \%$ of the total for developing countries. With 856 transactions, the region had the highest number of transactions during this period. In 2008, the region raised $\$ 16.7$ billion, down $60 \%$ from 2007. Turkey, the Russian Federation, and Serbia together were accounting for nearly $82 \%$ of regional value.

${ }^{6}$ Tables are omitted, here, due to confinable space, but are available from the author, in his manuscript, Kallianiotis (2011e).
} 


\subsection{A Theoretical Social Welfare Criterion: The Optimal Level of Privatization}

The expected objectives and possible effects and social benefits (SB) of privatization are the ones depicted in Graph 1 bellow, but there is a tremendous social cost or losses (SC) accompanying all these outcomes. The question is, here; are the social benefits of privatization exceeding its social costs $(\mathrm{SB}>\mathrm{SC})$ ? The answer is obvious by observing the reaction and opposition of all citizens, except of the international organizations and some liberal bureaucrats, who have some highly paid secured jobs and are ignorant of what is the ultimate social objective of a sovereign nation and its citizens. Public sector employees and private ones differ fundamentally in their acceptance of risk and they are exposure dissimilarly to economic shocks. Public sector employees enjoy extended dismissal protection and work in enterprises that very rarely go bankrupt. Thus, these workers face a reduced risk of losing their jobs, in comparison with employees in the private sector. For this reason, their compensation is lower than those who work in private businesses.

The evaluation of privatization must be from the point of view of the society's well-being and not from the profit maximization one of multinational firms. The total welfare of a country (given the factor endowments and the state of the economy) must be improved continuously. [Kallianiotis (2011a)]. General concerns about the state of the economy or anxiety about crime rate or high risk or job losses are affecting negatively the social welfare. Also, the measurement of social welfare (SW or W) requires some ethical and countryspecific standards, which involve internal and eternal value judgments. [Koutsoyiannis (1981, pp. 524-549) and Layard and Walters (1978, pp. 3-51)]. As a welfare criterion can be the growth of the wealth of the society (nation's GNP), which increases employment $(u \cong 0)$ and production (keeping prices stable, $\pi \cong 0$ ). This implies that the income distribution will be ethical and just (not exactly equal). A high (out of control) growth can lead to reduction in social welfare, due to waste, pollution, huge fluctuations of business cycles, creation of bubbles, irrational euphoria, and negative mental, physical, and spiritual effects on humans. Efficiency (saving of recourses) is very important in social welfare (respect of the creation and individuals). Financial markets stability (normal return) and low risk to attract longterm investments and prevent speculators and opportunists through regulations improves the wealth of the investors and their utility. We cannot accept an action, which increases some individuals' utilities, but one individual's utility is decreasing because all individuals are equal (have the same "worthiness"). The criterion must be objectively measured and Pareto-Optimal one. ${ }^{7}$

The optimal level of privatization of SOEs is where the SW or W is maximized. [max $S W \equiv W=S B-S C] .8$ This point is where the marginal benefits of privatization $\left(M B_{P}\right)$, due to increase in efficiency, productivity, government revenue, increase in capital market liquidity, reduction in national debt, etc. are offset by the marginal cost of socio-economic distress $\left(M C_{S E D}\right)$, due to increase in unemployment, reduction in public wealth, increase in dependency, creation of private monopolies, increase in prices, increase in risk, etc. Figure 1

\footnotetext{
7 According to Pareto-optimal criterion any change in our socio-economic system that makes at least one individual better-off and no one worse-off is an improvement in the social welfare.

${ }^{8}$ Where, $\mathrm{SW}=$ social welfare, $\mathrm{SB}=$ social benefits, and $\mathrm{SC}=$ social cost.
} 
shows that at zero $(0)[\% P O(P P)]$ ratio, ${ }^{9}$ the country has only SOEs, which provide high SB, but they also have a relatively high SC. At $100 \%[\% P O(P P)]$ ratio, the SOEs are zero $(0)$, we have only POEs, where the SC is huge and exceeds the SB (SC>SB). The optimal level of privatization is at point $\mathrm{B}$ (point of bliss), where the $\mathrm{SW}$ is maximized; the condition is: $M B_{P}=M C_{S E D}$. The objective of a government must be to privatize a proportion of the SOE as much as it is needed to reach the optimal ratio $\left(P P^{*}\right)$, which is below $50 \%$. After this point, the SW is falling and it is becoming negative closed to $100 \%[\% P O(P P)]$, actually, after $75 \%$ of privatization of the SOEs.

The social welfare function can be written as follows,

$$
\text { Optimize } W=f\left(u^{A}, u^{B}, u^{C}, \ldots, u^{N}\right)
$$

Subject to

$$
u_{i}=f\left[X^{S O E}, X^{P O E}, E^{S O E}, P_{G \& S}, P W, S \& S, N D, E\left(R_{P}^{G}\right), \sigma_{R_{P}}^{G}\right]
$$

(tastes, employment, socio-economic benefits, and investments in Treasuries)

$$
u_{j}=f\left[X^{S O E}, X^{P O E},-E^{P O E}, P_{G \& S}, P W, S \& S, N D\right]
$$

(tastes, unemployment, socio-economic benefits, and disinvestments)

$$
u_{u}=f\left[X^{S O E}, X^{P O E}, E^{P O E}, P_{G \& S}, P W, S \& S, N D, E\left(R_{P}^{P F}\right), \sigma_{R_{P}}^{P F}\right]
$$

(tastes, employment, socio-economic benefits, and investments in private securities)

$$
\bar{K}=K^{S O E}+K^{P O E} ; \bar{L}=L^{S O E}+L^{P O E}
$$

(endowments)

$$
X^{S O E}=f\left(K^{X^{S O E}}, L^{X^{S O E}}\right) ; X^{P O E}=f\left(K^{X^{P O E}}, L^{X^{P O E}}\right)
$$

(technology)

$$
R^{G}=C I F_{0} ; R^{P F}=-C O F_{0}+\sum_{t=1}^{\infty} \frac{C I F_{t}}{(1+i)^{t}}
$$

(revenue) $)^{10}$

Where, $\mathrm{SW}$ or $\mathrm{W}=$ social welfare, $u^{A}, u^{B}, u^{C}, \ldots, u^{N}=$ utility (happiness) of individuals $\mathrm{A}, \mathrm{B}$, $\mathrm{C}, \ldots$, and $\mathrm{N}$ in the nation, $\mathrm{SB}=$ social benefits, $\mathrm{SC}=$ social cost, $u_{i}=$ utility of persons working for a SOE and investing in government securities, $u_{j}=$ utility of persons who lost

9 Where, $\mathrm{POE}=$ private-owned enterprise, $\mathrm{SOE}=$ state-owned enterprise, $\% \mathrm{PO}=$ percentage of private ownership, $\mathrm{PP}=$ proportion of privatization of the SOE.

${ }^{10}$ Where, $C I F^{G}=C O F^{P F}$ and $R^{G}<R^{P F}$. 
their job, due to privatization and do not have any investment, $u_{u}=$ utility of unconcerned individuals, who are working for a private firm and invest in private securities, $\mathrm{SOE}=$ stateowned enterprises, $\mathrm{POE}=$ private-owned enterprises, $\mathrm{X}=$ commodity or service, $\mathrm{E}=$ employment, $P_{G \& S}=$ prices of goods and services, $\mathrm{PW}=$ public wealth, $\mathrm{S} \& \mathrm{~S}=$ security and safety, $\mathrm{ND}$ = national debt, $E\left(R_{P}^{G}\right)$ =expected return of a portfolio in government securities, $\sigma_{R_{p}}^{G}=$ risk of a portfolio in government securities (interest rate risk or maturity risk), $E\left(R_{P}^{P F}\right)=$ expected return of a portfolio in private securities, $\sigma_{R_{P}}^{P F}=$ risk of a portfolio in private securities, $\mathrm{K}=$ capital, ${ }^{11} \mathrm{~L}=$ labor, ${ }^{12} \mathrm{R}=$ revenue, $\mathrm{G}=$ government, $\mathrm{PF}=$ private firm, $\mathrm{BP}=$ before privatization, $\mathrm{AP}=$ after privatization.

The optimality conditions are:

1. Efficient consumption

$$
\left(\frac{u_{X^{S O E}}}{u_{X^{P O E}}}\right)^{i}=\left(\frac{u_{X^{S O E}}}{u_{X^{P O E}}}\right)^{j}=\left(\frac{u_{X^{S O E}}}{u_{X^{P O E}}}\right)^{u}
$$

2. Efficient production

$$
\frac{X_{L}^{S O E}}{X_{K}^{S O E}}=\frac{X_{L}^{P O E}}{X_{K}^{P O E}}
$$

3. Efficient Product-mix

$$
\left(\frac{u_{X^{S O E}}}{u_{X^{P O E}}}\right)^{i}=\left(\frac{u_{X^{S O E}}}{u_{X^{P O E}}}\right)^{j}=\left(\frac{u_{X^{S O E}}}{u_{X^{P O E}}}\right)^{u}=\frac{X_{L}^{P O E}}{X_{L}^{S O E}}
$$

4. Optimal investment ${ }^{13}$

$$
\frac{u_{\left[E\left(R_{P}^{G}\right)-R_{R F}\right]}^{i}}{\sigma_{R_{P}}^{G}}=u_{\left[E\left(R_{P}\right)-R_{R F}\right]}^{j}=u_{\frac{\left[E\left(R_{P}^{P F}\right)-R_{R F}\right]}{\sigma_{R_{P}}}}^{u}
$$

5. Social justice

$$
\frac{u_{X^{S O E}}^{i}}{u_{X^{S O E}}^{j}}=\frac{W_{u^{j}}}{W_{u^{i}}} ; \frac{u_{X^{S O E}}^{i}}{u_{X^{S O E}}^{u}}=\frac{W_{u^{u}}}{W_{u^{i}}} ; \frac{u_{X^{S O E}}^{j}}{u_{X^{S O E}}^{u}}=\frac{W_{u^{u}}}{W_{u^{j}}}
$$

${ }^{11}$ Assumed that $K^{S O E}<K^{P O E}$. Then, $K_{t+1} \uparrow \Rightarrow i_{t+1} \uparrow$ (with the privatization).

${ }^{12}$ Assumed that $L^{S O E}>L^{P O E}$. Then, $L_{t+1} \downarrow \Rightarrow u \uparrow$ (after privatization).

${ }^{13}$ The Reward to Variability ratio for individual $\mathrm{j}$ is zero $\left(R V^{j}=\frac{\left[E\left(R_{p}\right)-R_{R F}\right]}{\sigma_{R_{P}}}=0\right)$ because he has no investment. Historically, for the U.S. financial market, the average reward to variability ratios are: $R V^{i}=0.217$ (investing in L-T government bonds) and the $R V^{u}=0.421$ (investing in Large-company stocks). See, Ross, Westerfield, and Jaffe (2008, Table 9.2, p. 268). 

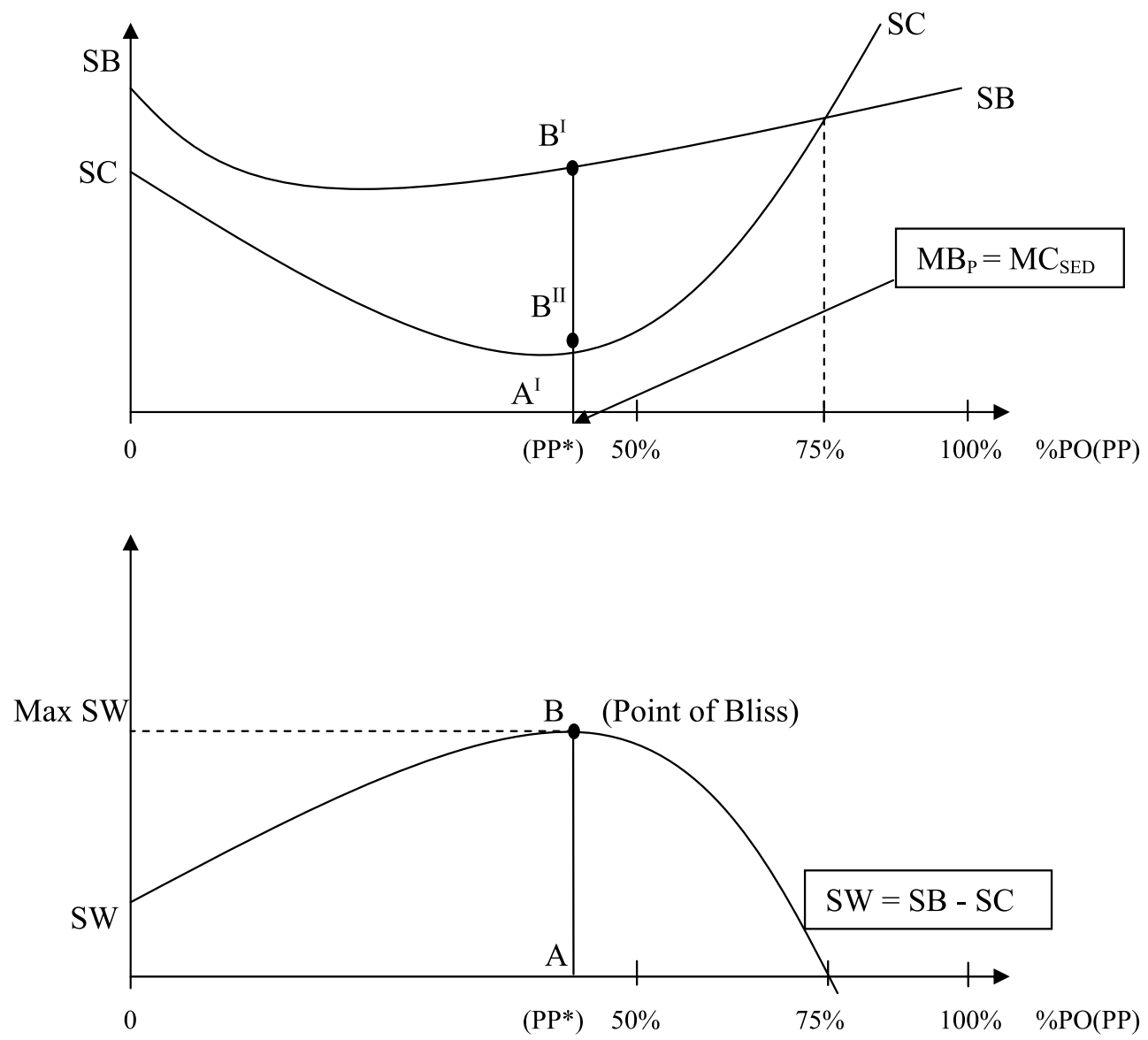

Note: $S W=$ social welfare, $S B=$ social benefits, $S C=$ social cost, and $(S W=S B-S C), \% P O$ or $P P=$ percentage of private ownership or proportion of privatization, $\left(P P^{*}\right)$ is the optimal level of privatization in the country, where the SW is maximized. The condition of optimization is: The marginal benefits of privatization must be equal to the marginal cost of socio-economic distress $\left(M B_{P}=M C_{S E D}\right)$. To the left of this point the SBs are high because of high employment, job security, low prices, big national (public) wealth, independence of government, high income, low risk, security and safety, and stability. Also, the SC is high because of inefficiency, low productivity, low production, subsidies, budget deficits, strong unions, and large governments. To the right of this optimal ratio $\left(P P^{*}\right)$, the SBs are high, due to efficiency of the private firms, higher productivity, more output, high profitability, higher revenue for the governments $(\mathrm{T})$, lower deficits, increase in government spending, liquidity in capital markets, and innovations. But the SC is high, too, because unemployment is high, reduction in public wealth, dependency on foreign capital and markets, private monopolists, higher prices, high risk, high bail out cost, social inequality, and redistribution of income (from domestic earners to foreigners).

Fig. 1. Effects of Privatization on the Social Welfare 


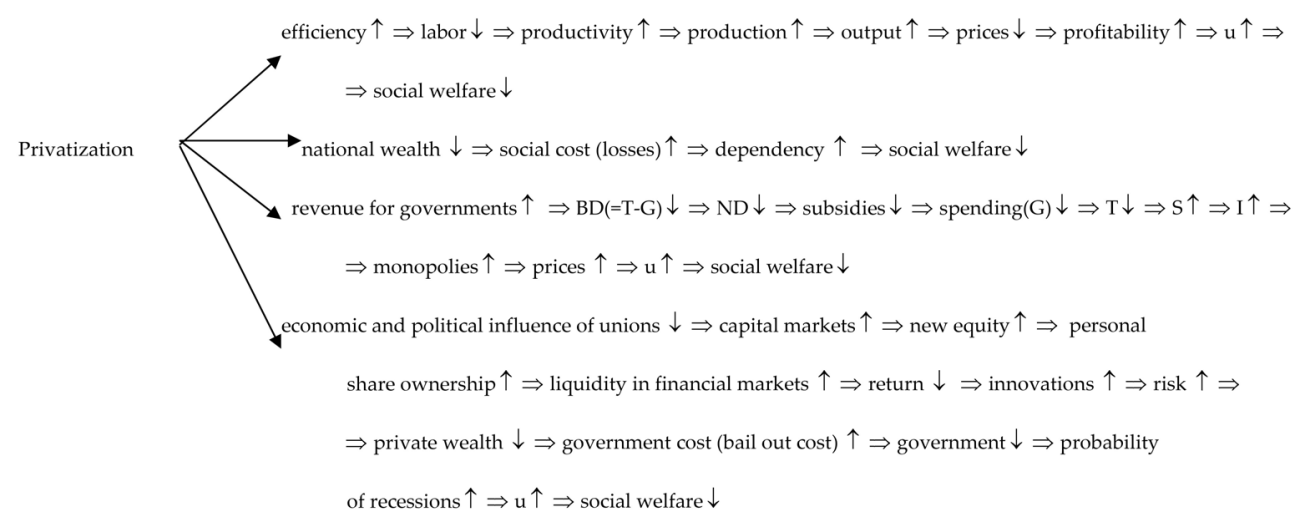

Note: $\mathrm{T}=$ taxes, $\mathrm{G}=$ government spending, $\mathrm{u}=$ unemployment rate, $\mathrm{BD}=$ budget deficit, $\mathrm{ND}=$ national debt, $\mathrm{S}=$ saving, and $\mathrm{I}=$ investment.

Graph 1. Effects of Privatization on the Social Welfare

6. Social wealth

$$
\frac{R_{B P}^{G}}{R_{B P}^{P F}}=\frac{R_{A P}^{G}}{R_{A P}^{P F}}
$$

With these 6 equations and 9 constraints, we can solve for the 15 unknowns. The unknowns are: $K^{X^{S O E}}, K^{X^{P O E}}, L^{X^{S O E}}, L^{X^{P O E}}, X_{i}^{S O E}, X_{j}^{S O E}, X_{u}^{S O E}, X_{i}^{P O E}, X_{j}^{P O E}, X_{u}^{P O E}, u^{i}, u^{j}, u^{u}$, $R_{A P}^{G}$, and $R V=\frac{\left[E\left(R_{P}\right)-R_{R F}\right]}{\sigma_{R_{P}}}$.

The above social welfare function [eq. (1)] must rise and this can happen only with individuals' happiness (utility). But, after a point, where the SC is increasing drastically, compared to the SB, the SW is falling. Our objective for this privatization is to reach a position, where we will make the groups of individuals $i, j$, and $u$ happier, without making anyone less happy. This will be an efficient social state. ${ }^{14}$ An appropriate factor ownership is necessary for any sovereign nation by keeping the SC at a minimum. The distribution of factor ownership must be such that each citizen, who is risk-averse, can buy the consumption bundle (and has the satisfaction that his country maximizes national wealth) with the income that his factor ownership generate to him and have some savings (that will be invested) in an environment that social and economic distress are at a very low level, which corresponds to the welfare-maximizing configuration of the national economy.

Undoubtedly, incentives are necessary for the public enterprises; but an uncorrupted, efficient, and acting in favor of the country government is imperative. Rewards to people, who work (have high productivity) and the opposite for the others are important. A wage differential must exist to public firms, too, but not a discrepancy of hundred of million of dollars, as it happen to the unfair private firms.[Kallianiotis (2011c)]. This will ensure reasonable utilization of labor and increase in productivity and efficiency. Public employees

${ }^{14}$ From the continuous demonstrations, we can see that the current privatizations are making many individuals unhappy. Then, our social state is not efficient. The PP ratio exceeds the optimal ratio (PP*). 
must be socially responsible and maintain a social discipline with education and continuous attempt for moral and ethical uplift. If state-owned enterprises make people feel happier, with the same consumption bundle and income, it is, other things being equal, preferable and promotes national security, self-sufficiency, independence, sovereignty, and social welfare. People working in the public sector are affected less strongly by general economic shocks than are people working in the private sector and their well-being is less sensitive to fluctuations in unemployment rates. Of course, the public sector attracts more risk-averse individuals than does the private sector. With a relatively large and efficient public sector, the country's risk is lower and the social welfare is higher.

Economic liberals claim that society is better off when allocation is done by the "dirty" speculators in the unregulated "free-markets", rather than by the exercise of a mixed power (political, social, economic, ethical, cultural, traditional, and others) to all citizens and markets. The negative results of globalization are already obvious from now to the entire world. Sovereign nations must undertake actions, which can be justified either on efficiency grounds, on equity grounds, and on cultural peculiarities, if the dark powers allow it to happen. The utilities of the citizens are interdependent and the social welfare function incorporates an ethical valuation of all citizens' individual utility functions, for this reason homogeneity plays a major role in nations' continuity. Leaders and scientists are responsible to determine the welfare-maximizing state (the "point of bliss", a state of perfection) for the entire society. We cannot provoke or scandalize or underrate any person in our society. Political leaders must refurbish their old power.

\subsection{Public enterprises and private firms: pros and cons of privatization}

The objective function of a public enterprise is completely different from that of a private firm. Thus, the main effect of privatization is the drastic change of the objective function of the SOE (public firm), when it is privatized. Public enterprises' objective is social prosperity:

$$
\max S P_{t}=f\left(E_{t}, Q_{t}, S_{t}, \bar{P}_{t}, \bar{R}_{t}, l_{t}, \phi_{t}\right)
$$

Subject to

National Constraints

where, $S P_{t}=$ social prosperity, $E_{t}=$ employment, $Q_{t}=$ output, $S_{t}=$ subsidies, $\bar{P}_{t}=$ low prices, $\bar{R}_{t}=$ decent revenue of the government, $l_{t}=$ equality among citizens, and $\phi_{t}=\mathrm{a}$ stability of the democratic nation factor.

On the contrary, private firms (POEs) are concerned mainly about profits:

$$
\max \pi_{t}=f\left(R_{t}, \bar{\xi}_{t}, w_{t}, i_{t}, \varphi, \sigma_{t}^{2}\right)
$$

Subject to

Social Constraints

where, $\pi_{t}=$ profit (or $\mathrm{V}=$ the market value of liabilities and equity), $R_{t}=$ revenue (price times quantity, $\left.P_{t}^{P F} x Q_{t}^{P F}\right), \bar{\xi}_{t}=$ executives' compensation, $w_{t}=$ real wage, $i_{t}=$ cost of capital, $\phi_{t}=\mathrm{a}$ firm specific effect, and $\sigma_{t}^{2}=$ a risk factor. 
Private businesses are producing, where marginal cost equals to marginal revenue $\left(M C_{t}=M R_{t}\right)$; actually, the private giant multinational firm is becoming a monopolist, with the lowest output and higher prices compared to the public one [eq. (15)]. Their first concern is the reduction of the labor cost, the increase in earnings by engaging in risky investment, the determination of CEOs' pay by themselves, and the maximization of the market price of their stocks. For this reason privatization has a large negative effect on white-collar employment, clerical as well as managerial because they have high wages. Liquidity in financial market will increase together with the inequality in salaries between the executives (counting in hundred of millions of dollars per annum) and the other employees (a few thousands per annum).

Public enterprises are more concerned about employment, which increases social welfare of the country. Then, the objective function of a publicly owned enterprise is more complex and broader [eq. (14)]. We assume that public firms are concerned first, about employment and second, about revenue for the government. The standard explanation for the public sector's concern for employment can be a "welfarist" [Bhaskar and Khan (1995, p. 270)] one (the public sector seeks to maximize social prosperity and consequently, social welfare). With widespread prevalence of unemployment in EU, after its integration and the uncontrolled inflows of illegal migration, a welfare-maximizing public-sector should push employment beyond the point, where the marginal cost equals marginal revenue. For this reason, output in public firms would also be greater than in private ones $\left(Q_{t}^{G}>Q_{t}^{P F}\right)$ and prices lower than in private firms $\left(P_{t}^{G}<P_{t}^{P F}\right)$. Further, excessive public sector employment could arise for another reason. The public sector might be used by politicians in order to create jobs in response to political pressure. This phenomenon is well spread in all over Europe and is called "clientelism". Also, public enterprises can be used by politicians to employ their voters and their family members; then, the reason is "canvassing". Finally, another explanation can be "sociological" and complementary to the clientelist and canvassing explanations, which is also political. This is a motivation of public sector managers in the determination of a pattern of excess employment. These managers create jobs for those to whom they are tied by kinship or social bonds. [Kallianiotis (2009, pp. 75-76)]. Of course, the above practices caused serious inefficiency and budgetary problems to EU nations.

Aristotle's social welfare plan had some secondary goals that served the ultimate goal. They were the stability of the democratic state (that we do today through enforcement, police, secret services, spying, and terrorizing the citizens) and the fulfillment of the state's ends, liberty and equality. Also, Aristotle's land distribution plan brought about a kind of parity between the rich and the poor. Today the chasm between these two groups is widening and the middleclass is in extinction (wiping out). ${ }^{15}$ The government should privatize only its most inefficient, heavily subsidized, and those that are not part of the national security of the country firms and also, the least likely to upset political and social interest groups, ones. The nation must have

\footnotetext{
${ }^{15}$ After twenty five centuries from Aristotle's moral and ethical philosophical teachings and twenty centuries since we have had the revealed truth, today's "democracies" are acting much worse than Hellas in her Golden Age and Roman Empire around the year 33 A.D. Aristotle (384-322 B.C.) was a great Greek philosopher from North Greece (Macedonia), who was a student of Plato (447-347 B.C.) and the teacher of Alexander the Great (356-323 B.C.). Plato was a student of Socrates (469-399 B.C.), the greatest philosopher of all times.
} 
high cohesion, solidarity, and patriotism among all stakeholders and preserve it for the benefits of all citizens and for its national defense, especially today with all these external pressures. Of course, to maintain SOEs ownership in domestic private hands, it will be preferable relative to sell them to foreign bidders (alienation of public wealth).

Further, the government has to intervene in all sectors and by using effective policies must make the market work more efficiently for the entire country. The social and economic policies must constrain the aggressive and unfair market behavior and produce socially acceptable results for all citizens. Governments must control efficiently all the social interest firms and there are many activities that fall into the government domain ("public goods"). These activities must be: national defense, public safety, public utilities (electricity, gas, water, telephone), public transportation (airlines, railways, etc.), public parks, the survival of endangered species, health care, postal services, agricultural banks, defense-related manufacturing, and certain strategic industries, economic infrastructure (electric power, water supply systems, sewage systems, telecommunications, rail lines, roads, tunnels, bridges, canals, seaports, airports and air traffic control system), some hospitals and schools, security services, and the criminal justice system.

It is well known, historically, that public goods cannot be provided by the free market. The value of these goods is hard to identify and to allocate among beneficiaries, who will enjoy them and will share their cost (through a fair and efficient tax system). The citizens need education, incentives, national conscience, social cohesion, resource users' fees, ownership rights, low taxes, no property taxes (on first dwellings) ${ }^{16}$ social prosperity, and common paideia, which would make it clear in their own interests to maintain the resources on a sustainable basis and bequeath them, even improved, to their children (the future generations). The market is weak to allocate costs and benefits; but, a fair, just, honest, impartial, lawful, truthful, uncorrupted, and objective government intervention must allocate costs and benefits of shared public goods effectively. As it was mentioned above, in the Politics, Aristotle urged democratic states to pay attention to both the wealthy and the poor. Then, our nations, today, with their anti-social policies, cannot be democracies! Aristotle warned that "poverty is the cause of the defects of democracy". (1320a 36-37). The current signs are proving this warning.

Privatization of industries with natural monopolies, such as a high-way, water supply, etc., could lead to abuse of monopoly power. Of course, improvement of efficiency is necessary and the government must be responsible to pursue this objective. Today, due to marketbased solutions; resource allocation, economic growth, efficiency, increase in government revenue, technological changes, etc., their ownership has shifted towards the private one and unfortunately, at a dramatic speed, without taking into consideration the negative impact on the citizens, due to the high risk of the financial market, where the private sector has to comply to its orders. There are cases that private-sector activities can exist-alongside with the public ones and when there is a need to transfer some to the private sector, the government must continue to hold $51 \%$ of the equity (as Figure 1 is showing) and be in a position to control the firm. The state ought to control a range of core economic activities that have strong public-good characteristics, which were mentioned above.

${ }^{16}$ Taxes must be on income. A home, in which a family lives, does not generate income; then, zero taxes. It has many expenses, mortgage payments, maintenance cost, insurance cost, etc. 
In summary; why governments are privatizing their public enterprises (SOEs)? Some of the reasons can be the followings:

1. To raise revenue for the inefficient and in debt nation through sale proceeds (usually, they are sold at a very low price) or to stop the financial drain from the subsidies. This objective is politically controversial because the nations (its citizens) lose for ever a potential stream of earnings in favor of some current sale proceeds that will benefit temporarily the party in power. The government can make this state-owned enterprise efficient and stop gradually the subsidies and the hiring of excessive employees. As the time is passing, the EU is going against the subsidies. It gave them at the beginning to avoid the reaction from the European citizens, who were and are against the Union. Further, the Maastricht Treaty imposes a 3\% budget deficit and member-nations have to sell all their public firms, even the national defense industry. Also, the EU wants to increase competition in the different industries by destroying national enterprises. The problem for Europe and Europeans is the European Union.

2. To promote economic efficiency in the internal operations of these public enterprises. But is efficiency the objective of these enterprises or to serve the citizens of the country? A healthy government must impose efficiency to the entire public sector; otherwise it will be better to resign. We do not need inefficient governments anymore. Their corruption is known from the media and they are making headlines everyday.

3. To reduce government interference and political expediency, which create distortions in the economy. But the voters can correct these distortions by voting out these politicians, who are against their own country. This situation is common today and it is impossible to find an uncorrupted politician; then, citizens try just to vote for the least bad ones.

4. To encourage competition and market-based discipline in these public enterprises. But, the country has to protect its industries, its labor force, its resources, its welfare, and its future. We must put the interest of the citizens first in priority and then, to consider the free market "values". Actually, the free market is value-free, too.

5. To support wide share ownership among the general population through the financial market. But, this market is corrupted and very risky, too, so the allocation of capital is completely inefficient and very risky. The reach people are paying low interest rate and the poor very high (due to high risk premium). [Kallianiotis (2002) and Ball (2009, p. 327)]. The proportion of population, which holds these securities is very limited, the return uncertain and the risk is increasing every day. For insiders and speculators there are enormous benefits, they are the only contributors to the profit function of these financial markets, today, but in the future they might collapse (already the financial distress, due to the current global crisis that they have caused, is very high and people are losing their hard working limited savings, which are invested for their retirements).

6. To respond effectively to globalization of industries and international consolidation. But, this trend leads to private monopolies and these ones are going to be worse than the public monopolies, without any control by any government. The current mania of privatization, forced by Troika, and the mergers and acquisitions will cause serious problems in the near future. ${ }^{17}$ Globalization is the worst economic system that has ever been conceived by any mind. This system will bring the globe to its end by reducing freedom (a heavenly gift), liberty, and social welfare to zero.

${ }^{17}$ As Figure 1 shows; the social welfare will become negative. 
Undoubtedly, it is important to increase productivity, efficiency, and welfare, but if this can be done with restructuring of state enterprises, there is no need for privatization. Public sector employment, especially of white-collar workers, is always excessive. Moving people from low-productivity jobs in state enterprises to unemployment does not increase a country's income, and it certainty does not increase the welfare of its citizens. The moral is simple in economics and in our lives: "Moderation is the best solution"; and human beings are very complex entities (persons) and not only a primitive economic being. Then, privatization needs to be part of a more comprehensive program and not because the suspicious IMF and the distrustful EU say so, which entails creating jobs in tandem with the inevitable job destruction that privatization often entails; but, if there are national security issues, privatization must be avoided, independently what the "experts" or the "globalists" are saying and the ignorant politicians are carrying it out. As many believe lately, globalization and technology have increased income inequality around the world. ${ }^{18}$ It is apparent to everyone that the performance of public enterprises has been far from satisfactory and they suffered sustained losses and were a major burden on the government budget, which is a serious ethical issue of our self-interest societies, today.

Likewise, the European financial markets are as inefficient, as the SOEs. New rules to cut hassle, expense of trades in EU started from October 30, 2007. They would eliminate many of the barriers within the EU. These new rules would open the way for European financial firms to compete with one another, force them to get the best prices for their customers and outlaw national financial-exchange monopolies. Despite years of efforts to create a common market, investing across borders in Europe remains an unachievable goal. The expectations are that the cost of trading stocks in Europe could fall by as much as $25 \%$ within a year, and investors will get more choice in financial services. Of course, services represent almost $60 \%$ of the value added of the EU economy and cover a vast spread of economic activities, from banks and insurance to data processing and management consultancy, to transport and tourism, and to legal and educational services. They play an increasingly large part in the economy and employment of the EU. [Moussis (2003, p. 94)]. This is a major disadvantage for the EU economies because the service sector is very vulnerable to business cycles; agriculture and manufacture are much more important and stable sectors.

\section{Regulations, public policies, and implications of privatization}

Stiglitz (2002, pp. 54-58) has stressed, from his work experience in government and international organizations, that the IMF and the World Bank [even the EU] have approached the privatization issue from a narrow ideological perspective (privatization was to be pursued rapidly). Also, scorecards were kept for the countries making the transition from public to private ownership (from communism to the market economy, actually, to globalization). Those who privatized faster were given the high marks. Through these pressures, privatization often did not bring the benefits that were promised. "The problems that arose from these failures have created antipathy to the very idea of privatization." The IMF, EU, and other international institutions assume that markets arise quickly to meet every need, but in fact, many government activities arise because free markets have failed to

${ }^{18}$ This has been said by four Nobel Laureates (Robert Solow, Finn Kydland, George Akerlof, and Robert Fogel). See, The Wall Street Journal, August 25, 2008, pp. A1 and A2. 
provide essential services. This is obvious everywhere outside the United States. Economists and political advisors, who have studied in U.S. universities, try to impose the same theories on their countries, but, these do not work because the structure of the economies, the culture, and the needs of the citizens are different, there. The private financial markets are also very risky and they have a negative effect on individuals' lives; for this reason a healthy public system must exist (like, the Social Security, the Unemployment Insurance, a National Mortgage Association, a Student Loan Supplier, etc). Eliminating the government enterprises may cause security problems (i.e., utilities, telephone, education, etc.), unemployment, and other types of suffering to the citizens, especially with the creation of private monopolies. Drogalis (2008) criticizes the American social welfare system comparing it with Aristotle's social welfare one. The same can be said for the European Union, which follows the U.S.A. (a general servile imperialism). Aristotle recommended that the state must gather together all "excess revenue" into a fund and distribute this wealth through block grants "sufficient for the purchase of a plot of land" or "enough to start men in commerce or agriculture" (1320a 39-46). Today, we take away all the wealth from the state (from the tax payers-citizens) with privatizations. Thus, we destroy the public wealth of the future generations.

The authorities believe (have been persuaded by some special-interest groups) that it is important to privatize quickly and deal with the issues of competition, regulation, and loss of national wealth, later. Of course, privatizing a public monopoly might increase efficiency and can yield some revenue to the government; but, the IMF and EU focus only on macroeconomic issues, such as the size of the national debt and government's deficit $(60 \%$ and 3\% of the GDP) according to Maastricht criteria, than on structural issues, such as efficiency and competitiveness of the industry, selling the public enterprises at a correct market price, ${ }^{19}$ morality and work ethics, incentives, employment, and indigenous value system. These new private monopolies will be more efficient in production than the government, but they will be more efficient in exploiting their monopoly power, too; employees and consumers will suffer. Privatization has a drastic impact on employment and this is the major argument against privatization and its social cost. There is truth on this issue and from the other side; the low productivity of the public sector (which is very unethical from the side of employees).These unproductive employees cannot be promoted, their salaries should be low, and they might lose their jobs, too. But, the profit of this new private firm is going to come from trimming the payroll and eliminating the permanent jobs to its workers. Economists, as social scientists, have to focus on overall efficiency (for the entire society) and not on specific firm's one. There are enormous social costs associated with unemployment and security costs associated with the foreign ownership of these new private firms, for which they do not care because their objective is different than the government's one. "Privatization often destroys jobs rather than creating new ones." [Stiglitz (2002, p. 57)]. Privatization, outsourcing, the moving of firms in countries with lower cost of production, and the illegal migration are some causes of high unemployment in Greece and in the entire EU.

\footnotetext{
19 Today, with this undervalued stock market, the sales of SOEs will be at an unfair low price, which does not benefit the government (less revenue) and hurts the citizens (less employment and income and high uncertainty).
} 
Furthermore, there can be a large social cost of unemployment (especially with the socialist and communist parties that exist in EU country-members), manifested by urban violence, increased crime, social and political unrest, reduction in wages, and employment of illegal immigrants because they are the only ones, who can accept a low pay job (reverse discrimination). Also, widespread anxiety exists even among workers, who have managed under pressure to keep their jobs, a broader sense of alienation floats in the air; additional financial burdens on family members, who manage to remain employed or receiving a low pension are appearing, the withdrawal of children from private schools because the parents cannot afford the high tuitions is following, and the tremendous financial distress and high probability of bankruptcy among households are, now, a fact. The cost of unemployment is huge for the unemployed person, his family, the financial market, and the entire society (by losing the skills of these people), and definitely, cannot be covered with some unemployment insurance. Their children without the appropriate education would be future unemployed citizens, too. The social cost is even higher when a public enterprise is sold to foreigners. Foreign owners feel only one obligation towards their shareholders (this is the only pressure from the market to maximize their market value by reducing costs) and less of an obligation towards the social policy of the host country (its social welfare). Their decisions are not based on patriotism or on any other social values; their "values" are greed, fear, corruption, exploitation, etc.

Every citizen in a country must care about high rates of unemployment, even when he himself is not unemployed. High general unemployment (the worst deficiency of the free market) reduces individual welfare by increasing social cost on the rest of the population. A high rate of general unemployment has negative effects on the population as a whole because of social effects, like higher crime rates, the imposition of higher taxes to finance increased welfare spending. Also, it increases the income inequality within the society, it affects people's well-being by reducing their sense of personal economic security, it depresses wages increases their actual or perceived risk of job loss and unemployment. Then, unemployment creates general negative externalities and externalities arising from changes in individuals' perceived economic risks. All these have a negative effect on the social welfare. The number one objective of public policy must be full employment $(u \cong 0)$.

Unfortunately, the most serious concern with privatization, as it has so often been practiced, is corruption, due to the corrupted participants (politicians and public servants). The rhetoric of market fundamentalism asserts that privatization would reduce what economists call the "rent-seeking" activity of government officials who either skim off the profits of government enterprises or award contracts and jobs to their friends or to those who pay higher commission. But also, privatization is jokingly referred to as "briberization". If a government is corrupt, there is very little evidence that privatization will solve the problem. After all, the same corrupt government that mismanaged the public firm will also handle the privatization; this might be a reason that the offshore banking is doing very well and Switzerland is prospered. These governments, by selling a government enterprise at below market price, they could get a significant chunk of the asset value for themselves rather than leaving it for subsequent officeholders. Competition among current and future politicians and parties has increased unfair privatization. "Not surprisingly, the rigged privatization process was designed to maximize the amount government ministers could appropriate for themselves, not the amount that would accrue to the government's treasury, let alone the overall efficiency of the economy. Indeed, sometimes [privatization] was associated with 
decline [growth] and proved to be a powerful force for undermining confidence in democratic and market institutions." [Stiglitz (2002, pp. 58-59)].

The major problems of our societies, today, are the "independent" central banks and the corrupted and powerless politicians. They use public enterprises to reward political supporters through mispricing of products and services, investment in low-value projects, cross-subsidization, overstaffing just to win the votes from their families, suboptimum plant location, without paying when they use their products or services, without contributing to their pension plans, and putting their incapable friends as managers. Due to these government corruptions, some academics believe that privatization of every industry will bring significant economic gains to the country, but they forget that the country is the citizens of it and their welfare, not a market-oriented economic efficiency at the moment and the perdition of the nation (its wealth and its sovereignty), later. Now, that the stock prices have declined so much, the sales of these SOEs do not generate any serious revenues to the governments. One of the reasons of the double digits unemployment rate in EU is the irrational privatization (combined with the other absurd behavior, the uncontrolled illegal immigration, the outsourcing, the tremendous imports, and the movements of businesses to other low cost nations). Free trade, free markets, and privatization, lately, restrained the social welfare. European governments are selling public utilities and telecommunication companies without having prior implemented any viable regulatory framework to govern these critical infrastructure activities newly allocated to the private sector.

Privatization promised important gains in the efficiency of resource allocation and the rate of economic growth through competition, but it does not mention its effect on employment and ownership of this new private firm, which is lost for the country forever. In the early 1990s all eyes were on Eastern Europe, where efforts ranged from successful mass privatization in Poland and Eastern Germany (after its reunification with West Germany). It is argued that over time (in the long run) privatization will lead to lower prices, improved quality, more choices, less corruption, less red tape, and quicker delivery. But, the existence of problems such as market failures, natural monopolies, and the planned financial crisis should limit this process. Currently, the greediness in the financial markets by the speculators, the political inaction, and the misinformation from the media increase the volatility in the stock markets, reduce consumers' and investors' confidence and economies can go back to a second recession (hopefully not a depression), which seems that this will be the future game by these unregulated market makers.

Also, governments have few incentives to ensure that public enterprises are well run and there is no comparison of these state firms with other ones, which makes them inefficient. The government administration has difficulty evaluating the efficiency of all these various state-owned enterprises (SOEs), but the voters know them because they deal with their services daily and they must not elect a party, which is running inefficiently their government. The government needs to have a reward and punishment system for the management of public enterprises and these firms must balance their books [revenue equals $\operatorname{cost}\left(R_{t}=C_{t}\right)$ ]. Of course, privatizing a non-profitable state-owned company, it has to raise prices in order to become profitable because there will be no subsidies (tax money) in order to cover its losses, so citizens would have higher cost. 
It is true that state-run enterprises tend to be bureaucratic, but a democratically elected government is accountable to the people through legislature, Parliament, and the other institutions must be motivated to safeguarding the assets, the wealth, and the welfare of the citizens of the nation. Private firms might run more efficient, but they serve only their own interest and the market's criteria; mostly, they are acting against the social interest. The government has to improve all public industries, which have to produce revenue to the government and offer services to the public; and also, to preserve the middle class. In Book 4, Chapter 12 of the Politics, Aristotle attributed the stability of democracies to the presence of an economic middle class. Our non-democratic societies, today, are destroying the middle class; this will be the end of the current civilization.

Corruption is common in the public sector, but it starts from the politicians. They are the example for the public and certainly, every leader is a prototype for the people. The decisions must be made for the public benefits and not for political or personal gains. The voters are responsible to elect the highest ethical, moral, patriotic, and efficient politicians (the best among the people), too. If politicians are corrupted, during the privatization process, they will sell the assets in significant under-pricing terms and they actually care for their commission and not so much for the government revenue or the financial markets or the social welfare. The managers of the public enterprises must be accountable to the minister, who supervises them because all of them are accountable to the broader community and to political "stakeholders". The public does not have any control of private firms and lately, governments have lost completely their control or oversight of private companies. They invest wherever they want to maximize their profit, usually outside of the country; they lay off workers to minimize their costs, and serve poorly the needs of their customers and destroy the environment. The government cannot impose any social constraints on these giants and the anti-trust laws are not applied anymore.

A democratically elected government can intervene when civil liberties are threatened by the public enterprises and through these controls can satisfy the social goals and benefit the nation. With respect to capital, state-owned enterprises can borrow money from the government that raises it in the financial markets more cheaply (by issuing government bonds) than the private companies. ${ }^{20}$ Investment decisions are based on market interest rates (cost of capital), then, private firms cannot promote efficient investments. Government is also sensitive to job losses, but the private industries are exactly the opposite, they show high sensitivity of profit losses, on taxes, on restrictions, and to the market value of their stocks. Government chooses to keep certain public companies and bail them out because of their strategic importance or national security. Poorly managed state companies, instead of going bankrupt or sold to a private firm, must have their management removed, especially if the management had been appointed by the previous party in power and now is against the policy of the current one, which is in government.

If a government-owned monopoly, which provides an essential service (i.e., water supply or electricity) to all citizens, is privatized, its new owners could lead to the abandoning of the social obligation to those who are less able to pay or to regions, where this service is unaffordable (like, remote islands). These enterprises must be state-owned because the anti-

20 Except now that the government bonds have been downgraded and their cost has increased drastically. 
trust laws do not work anywhere today and the private firm will become a monopoly and the citizens will be in trouble (exploited). The profit of private enterprises ends up to stockholders after executives' payments; the majority of them are foreigners and the workers of the company have to accept low wages because these shareholders need high return on their money. Unemployment and low income is possible from these "competitive and efficient" private firms. Governments can exert pressure on state-owned enterprises to help implementing public policy [maximization of social prosperity: $\max S P_{t}=f\left(E_{t}, Q_{t}, S_{t}, \bar{P}_{t}, \bar{R}_{t}, \imath_{t}, \phi_{t}\right)$ and then, social welfare: $\left.\max W=f\left(u^{A}, u^{B}, u^{C}, \ldots, u^{N}\right)\right]$. Also, they can buy supplies from local producers (creating more income and employment domestically) and not from abroad, where quality is questionable. In addition, the public enterprise can lower prices to satisfy domestic policy of lower inflation, increases in demand, and reduction in unemployment. SOEs act anti-cyclically, but POEs act exactly the opposite, pro-cyclically.

A private firm over-react to short-term events (small recessions) because the financial market presses it to show high earnings and profit; otherwise the stock prices will fall, because this is, unfortunately, the ultimate objective of the firms that the market is imposing on them (market has become the only god, at least they are not atheists) and try with all their means to maximize their value $\left[\max V=D+P+S\right.$ or $\left.\max \quad V=\frac{E(E B I T)(1-T)}{i}\right] \cdot{ }^{21}$

Private companies are downsizing even in periods of economic growth, just to increase even further their profits. Their advertising cost is also outrageous. The uncontrolled private firms opposed to the needs of the majority, to the welfare of the nation, and thus, they are anti-democratic and because they are in control of our society, our democracies are in collapse (in social dissolution). Our society needs a better social and humane socioeconomico-political system after thousands of years of experience, knowledge, and improvements. The voters are responsible for the leaders they elect and the inefficient leaders must feel the pressure of future elections, where they will not be elected. Now, with this global financial crisis, the best could have been to have some nationalizations and improvements in stability and increases in employment and welfare. The shareholders (especially, the institutional ones) have the responsibility to control the outrageous CEOs' compensation. ${ }^{22}$

Needless to say, many industries must stay public, like, prisons, basic health care, and basic education. Utilities that provide benefits to society at large and produce no profit, like defense, must stay public, too. All natural monopolies are not subject to competition and then, they can be better administrated by the government. Also, regarding corruption; the sales (privatizations) themselves give a large opportunity for grand corruption. Privatizations in many countries were accompanied by large-scale corruption during the sale of the state-owned enterprises. Those with political connections unfairly gained large

${ }^{21}$ Where, $\mathrm{V}=$ market value of the firm, $\mathrm{D}=$ market value of debt (bonds), $\mathrm{P}=$ market value of preferred stocks, $\mathrm{S}=$ market value of common stocks, $\mathrm{E}(\mathrm{EBIT})=$ expected earnings before interest and taxes, $\mathrm{T}=$ corporate tax rate (fiscal policy instrument), and $\mathrm{i}=$ market rate of interest (monetary policy instrument).

${ }^{22}$ What is the marginal product of labor of a $\operatorname{CEO}\left(M P_{L}^{C E O}=\bar{\xi}\right)$ that justifies compensation $(\bar{\xi})$ more than a $\$ 1,000,000$ per annum ( $\$ 83,333$ per month, $\$ 4,167$ per day, and $\$ 521$ per hour)? See, Kallianiotis (2010a). 
wealth, which has discredited privatization in these nations, as the media have reported widely.

Privatization has faced and will face opposition from entrenched members of the existing management concerned about losing their positions, from labor groups concerned about job losses in subsequent business restructuring or from local interest groups, linked industries that might be adversely affected by a change in ownership, and the citizens of the country by losing their national wealth. Unfortunately, governments do not listen to such opponents because of their power, the pressure from EU and the IMF, and the global trend. Political opponents are often eager to use the issues raised in the privatization debate for political advantage, but when they will be in government, they act the same way. Many times, there is no transparency, fairness, objective selection criteria for possible private-sector buyers, for investment bankers or for facilitators of the privatization process and the country and its citizens experience tremendous social costs.

Usually, state own enterprises will command a very low price, which is far below book value (politicians are charged of "giving away" these public firms). There are possible longterm liabilities involving environmental and health issues that the new owners may not want to take on and which require some kind of government guarantee. [Walter and Smith (2000, p. 179)]. Evaluating the condition of a state-owned enterprise (SOE) is often complex and difficult. The government is forced to accept a "realistic market value", which is not fair for the country and its wealth preservation, because always it is below book value. The valuation techniques, used for private enterprises, cannot be used, here, because they are not suitable to the situation. What will be the appropriate discount rates needed for this valuation? The complexity of taxes, regulations, unions, investment bankers, role of foreign investors in this privatization, which might cause serious security issues for the country, due to corruption, favoritism, and inefficiency of the government officials make the correct valuation impossible.

Finally, a large number of shares of a privatized firm must go to employees of the stateowned enterprise (SOE) because these employees have contributed, materially and intellectually to the value of the firm and therefore, a stake in its ownership must go to them or only employees as owners may improve performance of this private firm. Of course, the worst thing for the firm's labor could be extensive layoffs and personnel changes. Even the great Greek philosopher, Aristotle, understood self-sufficiency, which build state stability. A person must participate in the activities of the state in order to achieve his natural end and love it, as his own country. The ideal city (state) supports "mere life, it exists for the sake of a good life". [Aristotle, Politics (1252b27-1253a1)].

Alternatives to shifting ownership to new investors (privatization) include leasing and operating concessions, but the social benefits are also insignificant (there might be social losses). (1) A build-operate-transfer contract may involve the sale to a private company of a concession to undertake an infrastructure project, like a bridge or tunnel, and to operate it on a commercial basis for perhaps 30 years, after which the project reverts to the government at no cost or at a price, but the value of this asset will be relatively low (completely obsolete) at that time and the maintenance cost very high. The benefits for the government can be insignificant. (2) A facility such as a resort or a seaport or a canal may be leased to a private operator for a fixed period against mutually agreeable performance requirements and financial terms, but the risk is that workers will be layoff and the state is 
losing temporarily its wealth. (3) A state-owned enterprise (SOE) may be placed under a management contract with a private operator, who has the necessary expertise to maximize profit by minimizing cost (labor cost mostly), which will affect negatively employment. Thus, the social welfare is not improving and the revenue for the government from the leases is negligible. ${ }^{23}$

The above approaches are difficult for the state and the labor of the country and the results are the same as transferring ownership to private enterprises. Such transfers are common in EU by all socialist and centrist governments. Governments might give up operational control in privatizations via share offers, but they have to retain veto power through the corporate charter with regard to choice of the CEO, maximum allowable foreign shareholdings, and by retention of a "golden share" (more than 51\%), which enables them to block certain corporate action that would go against the social welfare of the country, especially during periods of financial crises and recessions, as Figure 1 shows.

Of course, as it has been mentioned above, the efficiency gains from privatization emanate from the monopoly power that the private owners have after privatization of this SOE and from the operational efficiency, due to superior management of this new private firm. Utilities and other government services fall into this category and the private owners are benefited immensely after privatization (exploitation of monopoly rents). The private firms' shareholders (who are mostly foreigners) clearly benefit from the increased profits. This increase in cash flows reduces the default risk of the company's debt-holders and consequently the risk premium, and the cost of capital.

It will be in the country's advantage and in the government's political interest to ensure that SOE ownership remains in domestic private hands. For doing this, the government has to offer domestic bidders tax breaks or other subsidies in order to ensure that they remain competitive against foreign bidders for this SOE. Of course, the government may legally restrict foreign buyers from bidding for the SOE for security purposes. Privatization has been so far "politically successful" in EU; it has been endorsed and overseen by a wide spectrum of political opinion (all the "new age" parties) and has become, with the passage of time, generally accepted (imposed by force); notwithstanding some epic battles over particular privatizations. Unfortunately, the trend is, "the market knows best" and there is no need to have public approval through referenda. But, it proved in 2008 that the market does not know and its ignorance caused serious problems to the global economies, which are not over yet, after four years.

Unremittingly, institutional investors have mostly participated in EU privatizations. An important question is the extent to which foreign investors should be included as eligible buyers in privatizations. There are strong national security arguments against limits to

\footnotetext{
${ }^{23}$ Greece has leased the seaport of Piraeus to a state-owned Chinese firm, Cosco, for 35 years and people lost their jobs. Also, Chinese are bringing everything that they want to Europe, which affect negatively employment, income, and tax revenue in Greece and the entire Europe. See, "China's new Silk Road into Europe", The Telegraph, August 19, 2011.

http://www.telegraph.co.uk/news/worldnews/europe/greece/7869999/Chinas-new-Silk-Road-intoEurope.html.

See also, Louisa Lim, "In Greek Port, Storm Brews over Chinese-Run Labor", (npr.org, August 25, 2011). http://www.npr.org/2011/06/08/137035251/in-greek-port-storm-brews-over-chinese-run-labor?sc=emaf
} 
foreign participation. [Markusen (2001)]. Privatization is at its root a very local business with strong political links. For investment bankers themselves, few sources of revenue are more attractive than the kinds of fees that can be earned in privatization transactions. They put their firm's skills and knowledge to work without necessarily committing its capital, and the fees (commensurate with the value-added of the service) are usually considerable. With the current trend of globalization, mergers and acquisitions (M\&A) and privatization have become worldwide social problems of wealth deprivation (wealth transferring from citizens to multinationals).

At the end, these advisers (investment bankers) on privatization, initial public offerings (IPOs) between 1985 and 1999, made $\$ 167.2$ billion in proceeds by involving in 488 issues. Advisers on privatization, seasonal equity offerings (SEOs) from 1985-1999, had as proceeds $\$ 462.4$ billion in 4,936 different issues. [Walter and Smith (2000, pp. 194-195)]. Then, privatization continues to be an active business for investment bankers (and they are the initiators of this process in many cases), ultimately they will transfer everything to the private sector and countries will end up without any assets and without any national wealth. Europe has been the primary scene of complete privatization, due to the pressure from the EMU (Maastricht criteria) and the IMF (debt crisis). Historically, before the integration of these countries the role of state-owned enterprises (SOEs) was unique and the unemployment was in the region of $2 \%$ in Europe. Now, they are basically "sold out" and the social problems are increasing (there are regions with $40 \%$ unemployment rate). Of course, their leaders will sell everything and EU will remain for a long time attractive arena for investment banks ${ }^{24}$ to maximize their objective functions against the citizens and the nations' objectives. Our problem is that we do not have good sets of data, which could allow us to infer statistically, by running different tests, validating the effects of privatization on financial markets (liquidity), on employment, on output, and on social welfare.

The European integration under the common currency, the euro, has created a complex relationship between the structure of the financial systems, the uncontrolled enterprises and speculators, and the nation, which has lost its public policies [Kallianiotis (2011a)] and its sovereignty and cannot exercise any control. The financial system plays a limited role in corporate governance, in determining to whom management reports and the performance standards to whom management is held. It tries to allocate capital to the most productive uses and denies it to the less competitive small local businesses. The uniform approach to corporate control (actually, immunity) will ultimately destroy the small domestic firms, which have traditionally existed in the national economies, created jobs, entrepreneurship, and established a social environment. It is necessary to save small businesses in every country.

We may see some growing opportunities for external financing of large corporations in Euro-zone, with lower cost of capital and competitive performance, but the reduction in labor cost has affected negatively workers, with their downsizing and their only focus on shareholders value and executives' compensation. The market capitalism acts in the interest

\footnotetext{
${ }^{24}$ Investment bankers caused the current financial crisis, which led countries to chaos and citizens to suicide. Russian Prime Minister Vladimir Putin said that "Today, investment banks, the pride of Wall Street, have virtually ceased to exist." See, http://www.marketwatch.com/story/russias-putinfinancial-system-has-failed
} 
of shareholders to maximize their wealth. The CEOs determine by themselves their payments, which are in tens and hundreds of millions of dollars per annum. Agency problems exist and growing. A small financial crisis led these oligopolists to financial distress and governments have to bail them out. All political parties have become neoliberals and governments have lost completely their control towards irresponsible multinational firms and towards the guided media, which provide any propaganda that they want as news and shape the public opinion the way to satisfy anti-national policies and anti-social objectives by receiving very high compensations. [Kallianiotis (2010b)].

The CEOs compensation reached \$250 million per annum. “Wall Street's five biggest firms paid more than $\$ 3.1$ billion in the last five years to their top executives, while they presided over the packaging and sale of loans that helped bring down the investment-banking system. Merrill Lunch \& Co., once the largest U.S. brokerage, paid its chief executives the most, with Stanley O'Neil taking in \$172 million from 2003 to 2007 and John Thain \$86 million after a month's work last year [2007]. ... Bear Stearns Co.'s James 'Jimmy' Cayne made \$161 million before the company collapsed and was sold to JPMorgan Chase \& Co. Goldman Chief Executive Officer, Lloyd Blankfein, made \$57.6 million in 2007 in salary and bonus. Co-presidents Gary Cohn and Jon Winkelried each got \$56 million. Morgan Stanley's current and former chief executives, John Mack and Philip Purcell, were paid about \$194 million over the last five years. The ex-U.S. Treasury Secretary, Henry Paulson, who was the former Goldman Sachs Group Inc. CEO, received about \$111 million between 2003 and 2006. (Democrats and Republicans in Congress were demanding that limits be placed on executive pay as part of the $\$ 700$ billion financial rescue plan proposed by U.S. Treasury Secretary, Henry Paulson, who said in testimony to Congress on September 24, 2008, that he would accept such limits as part of the plan after initially opposing them). Goldman Sachs had the highest total executive pay, of $\$ 859$ million, followed by Bear Sterns at $\$ 609$ million. CEO pay at the five firms increased each year, doubling to $\$ 253$ million in 2007. (Executivecompensation figures include salary, bonuses, stock and stock options, some awarded for past performance)."

Shareholders and boards should have done something about this robbery of the firms and society a long time ago. These people cannot make more than $\$ 1$ million per year! This is a crime against humanity! This corrupted system increases inequality, iniquity, social injustice, indifference, and destroys our traditional moral and ethical value system. The amazing is that employees are making this big money only, if they work in Wall Street, in Hollywood or if they are soccer players. Does it tell something for the trend of our falling society? The American people, as well as the Europeans are very angry about executive compensation and they are absolutely right. Of course, the foreigners, when they hear these figures, their anti-capitalism is increasing. The U.S. government and the regulatory authorities have a weak record when they come to regulating compensation and it seems that nothing will happen and the Western economies will follow their negative trends. It is impossible the compensation committee or the general counsel or the head of human resources to negotiate a pay package with someone who will be their boss in a week; it is a vicious cycle, here, and there are always too many loopholes. Then, the system will collapse.

Firms' objective of value maximization, [ $\max V=D+P+S$ ], without any constraints [social, moral, ethical, legal, environmental, etc.], causes serious social (welfare) problems. Free market mechanism has even destroyed democracy (which needs a moral, ethical, and 
legal environment to exist). Governments are controlled by businesses and lobbyists. Inefficiency has become the trend in the markets, due to excess profit, speculation, inside information, corruption, labor exploitation, cartels, price control, price discrimination (depending on the price elasticity), formation of public expectations, and other frictions. Corporate lobbies are seeking to pursue only their policy. Governments provide the regulatory and legal structure and the institutions, within which businesses function and enjoy social safety, security, tax shields, a productive labor supply, a huge market for their products and services, and everything they need. [Kallianiotis (2003 and 2002, p. 55)].

From the stakeholders of corporations (managers, shareholders, customers, and workers), workers and customers have the least rights and privileges, are last in priorities, and their interests are not satisfy. People (citizens) carry the burden of everything in a nation, not the businesses and not the governments. Actually, they are property-holders, but the government with the taxes, businesses with the high prices on goods and services, and the banks with the high interest on loans and low interest on deposits, take all people's surplus away.

Laissez faire economy needs some government regulations, but the government has to be independent and a true democracy, which is a very rare form of government, today. Politics and markets are inseparable; actually, politicians obey to the powerful markets ("money talks"). Of course, relations between government, banks, and industry are antagonistic, because the interest of the first is the social interest and of the seconds is the self-interest. Unfortunately, markets are short-sighted, acting against the social interest, and procyclically. An example can be the oil companies, which had raised the price of oil to a level, which caused a global recession. The deregulation of the financial markets since 1980 caused this enormous financial crisis in 2008. On October 23, 2008, the former Fed chairman, Alan Greenspan, during a testimony on Capitol Hill, admitted that he made errors been against regulations and keeping the interest rate at $1 \%$ for a long period. Furthermore, credit-default swaps (CDSs), which allow banks and other lenders to buy insurance against borrowers going bust, have cause serious problems to the borrowing countries and the financial markets. Europeans are asking for more regulations of these "toxic" speculative instruments and more transparency, especially lately, with the debt crises of the GIPSI ("PIIGS") nations in Euro-zone. Further, the EU was considering a ban on speculative derivative trades, including credit-default swaps, which have been blamed for worsening the crisis in Greece.

Of course, the central issue in Europe can not be the free-market model, but the economic and social well-being of the sovereign nations. The labor force is losing, daily, its previous rights and achievements. The illegal immigrants (the substitute of labor force by business) are contributing to these employment problems. Lately, the physical capital (wealth) belongs to foreigners; the technological changes are so drastic, which is difficult to follow by citizens and very costly to businesses, the long-term unemployment is very serious, the international trade (imports from China and developing countries) has destroy domestic economies. The primary (agriculture) and secondary (manufacturing) sectors are disappearing from Europe, as it has happened in the U.S. They have to protect their domestic industries and to enforce antitrust laws because oligopolists are thriving and monopolists are coming to replace them. There can be no antitrust exemptions, if they want to protect a little the fair competition and small businesses. Governments have to be in control of the anti-social free-market. 
The root of any problem in EU lies in the political process itself and in the weak (servile) politicians. Each EU country-member was structured by idiosyncratic founding circumstances, culture, civilization, and social structure, different points of departure for each nation imprinted their own mark on their evolution and for some on their thousands years old history (with common nationality, religion, language, etc). Homogeneity is absolutely necessary for nations to survive and accomplish great things in their journey in history. National societies in each of the countries participating in the euro, instead of accepting this new currency were and are against it, which has caused tremendous inflation, inequalities, increase in cost, reduction in foreign investments and exports, and has affected negatively social improvements and growth because public policies have been lost. [Kallianiotis (2011a)]. Financial systems and economies are negatively affected by the growth in incomes of illegal immigrants and the excessive profits of businesses. Lately, a large proportion of population entrusted their assets to financial markets (stock exchanges) by taking them out from banks (traditional savings) and now, with this global crisis, they lost completely their wealth. Also, the occupation structures changed; they destroyed farming (that means destructions of villages and small towns) and small businesses (destruction of entrepreneurs).

Lastly, the role of the ignorant, but powerful bureaucrats is tremendous in Europe (Brussels) and the structure of powerless governments is not very stable in some countries. The style of public policy varied considerably, both overtime and between the countries. In all European countries, the exploitation of labor, the financial disaster of 1929-1931 undermined the legitimacy of capitalism, leading to a general sidelining of securities markets and a high degree of formal regulation. Marxists and socialists favored extensive nationalization and a "social market economy", where government regulators set the legal parameters, within which market processes could evolve. After 1960s, with fiscal policies, they stimulated the economic growth by issuing extensively government bonds, which promoted the expansion of the government bond markets. Then, trade was growing and the operation of multinationals developed the financial markets, Euro-currencies markets, and Eurobanking. The pre-transition phase of Europe was characterized by inflation, high growth and full employment, banks were state-owned mostly, very little corporate bankruptcies, inadequate control over monetary aggregates and credit, an intellectual battle of ideas among economists and within the media, and an increasing vulnerability of the currency (at least, countries have as tool the devaluation of their currencies for pursuing trade policies) and of the domestic financial system to external sources of disturbance. Then, it came the integration in 1990s and the global financial crisis in 2008, which made Europe an oppressive and in debt continent, begging IMF for loans, third-world, poor and unemployed, unrecognizable mixture of Europeans and non-Europeans, but called them "European citizens". These debt crises are going to deprive EU nations of their public wealth with the imposed privatizations by the Troika. This is a true social crisis for Europe (social dissolution)!

\section{Concluding remarks}

Assessment of the comparative performance of the different enterprises owned by private firms (POEs) or by governments (SOEs) is basically impossible, due to the complexity and social effects and due to political pressure and expediency. The Euro-zone had evolved surprisingly quickly (overshooting) into one of the most attractive hotly contested financial 
markets, through privatization, in the world; but, what are the social benefits of market users and of the nations? By pure economic measures, we might say that there was economic welfare, but there was no social one. The savers (investing in the stock market) lost their money in the year 2000 and 2008, and many of them had sold their real assets and used this liquidity to invest in financial assets promising an outrageous return (without mentioning the risk of their investments). Employment has also been negatively affected. The Euro-zone might have created some opportunities for the financial markets, but their risks have caused the cost to exceed the benefits. Thus, we can assert that with privatization, we will benefit from the high liquidity, which is created in the financial markets; but its social cost offsets the social benefits.

Privatizations have been motivated by a range of different subjective goals and suspiciously imposed objectives; many have nothing to do with efficiency or social welfare. Some goals are fiscal; raising money from the sale of public enterprises in order to reduce deficits and pay for the current government expenditures, due to its inefficient management and corruption. Also, privatization is reducing the economic and political influence of unions, which is against workers' interest. These new private firms with their shares will stimulate and develop the domestic capital markets and provide more investment opportunities (share ownership) to wealthy citizens, to pension funds, to institutional investors, and to foreigners. Finally, the economic importance of the government will be reduced and the private firms (multinationals, Arabs, China) will take over (economic imperialism, globalization, etc.) the entire national wealth.

In assessing the impacts of privatization, there is statistically a problem of selection bias because the choice was not random. The privatization is more likely to occur to badlyperforming state-owned enterprises, than to the whole sample of SOEs. Then, the conclusion that privatization improves corporate performance based on the post-privatization experience of these selected firms, it is true; because they were the worst firms owned by the government. Some people say that phone rates have declined substantially, due to privatization of telephone companies, but this can be due to deregulation, competition, and drastic technological changes (in switches, optic cables, mobile phone technology, outsourcing, and numerous other innovations), lately. With the higher prices before, the state had high government revenue; now it has to raise taxes from other sources and increase borrowing. Then, lower prices cannot be interpreted as welfare-improving; especially, for the unemployed citizens.

Other people are saying that privatization improves profits and share prices of the new private firms. Evidence has shown that profitability has been improved, but the rise in share prices is due to the politically-motivated under-pricing of the initial share issues. All the benefits are going to the financial markets insiders. This is actually a transfer of wealth from taxpayers (citizens) to share owners (foreigners) and facilitators (investment bankers). Unfortunately, privatization leads to significant labor-shedding and consequently to improvements in labor productivity. Then, the labor-shedding is the dominant source of post-privatization improvement in profitability. But what about the social welfare with so many people unemployed or displaced to low pay (minimum wages) and unsecured or part time jobs?

Furthermore, many economists have proved that privatization has not been an economic miracle, but only a part of the wider liberal ("new age") restructuring and trend in the 
global economy after 1980s (globalization), involving imposition of higher taxes, public spending restrictions, destruction of trade unions, increasing "flexibility" (exploitation) of labor, etc.; but, the GDP growth and employment have not increased as a result of privatization. Ownership of a large section of the economy (nations' endowments) has been transferred (redistribution of wealth) from public hands (citizens) to private ones (foreigners). We have created inefficient and unequal material opportunities republics (but not democracies) by introducing different non-traditional valuation techniques. We, with our approvals and popular writings, destroyed the nuclear families, the villages, the small towns, family businesses, and the sovereign nations, and call our-selves social scientists. Politically, because of the trend and pressure, there is a strong, but wrong perception that this has been important and successful for them. The question is here, what the future politicians are going to sell? There will be no national wealth anymore. Then, the current politicians have not only caused serious problems to their citizens, but to their future colleagues, too.

The welfare of public sector workers is affected differently by economic shocks than is the well-being of private sector employees and this is an issue of political economy. In many EU countries, public sector employees constituted a large force in the electorate. As voters and as officials implementing social policies, they have a large influence on the legal rules governing the private labor markets. Their interests are not aligned with those of private sector employees. Public sector employees do not benefit directly through enhanced market power and increased salaries in the private labor market because these actions are increasing uncertainty and cost of production. Hence, they should be more inclined to abolish private-sector protections that discourage firing, such as severance pay, advance notice requirements, and seniority rules, policies that may result in persistent unemployment. Public servants enjoy some economic rent, too. This can be called a bureaucratic rent or utility premium of government sector workers relative to private sector ones and can be caused by high wages, fringe benefits, and job amenities or by the possibility of extracting bribes. High economic security enjoyed by public sector employees is a valuable fringe benefit of public sector employment that should be taken into account when we analyze the social welfare loss, due to privatization. During the current debt crisis, the pressure from the lenders for reduction of the public sector has affected negatively the social welfare.

People need "good life self-sufficiency", which includes sufficient work, sufficient property ownership, sufficient wealth, sufficient education, sufficient leisure time, and sufficient progress. People need to reach human excellence (perfection) and they need self-sufficiency, safety, security, and certainty for developing virtues. Then, people need private property ownership and nations need public property ownership. State ownership makes people to be co-owners and cultivate civil friendships, love, patriotism, and become involved in the life of the state (homeland, nation). The end of an Aristotelian democracy is liberty and equality. Of course, five centuries later, we adopted new superior virtues, through revelation. We expect people to reach, through work, a certain level of self-sufficiency, but privatization eliminates their right to work and confines their national wealth. Thus, we have to find the optimal level of privatization that maximizes the social welfare. This is the point where the marginal benefits of privatization (revenue to the government, efficiency of the private sector, reduction of deficits and debt, increase in liquidity of the financial market) is equal to the marginal cost of a socio-economic distress (increase in 
unemployment, loss of income and public wealth, dependency on foreign capital, private monopolists, higher prices, high risk, bail out cost), which can be written as $\left(M B_{P}=M C_{S E D}\right)$.

The social welfare systems, today, have failed to sufficiently satisfy even the basic needs of mere life for all individuals. The first problem that arises from privatization is the failure of the system to create a balance between the rich (who are now the owners of the private firms) and the poor (who are now unemployed, due to privatization). The wealthy people rule in our societies, both directly and indirectly; with their money they erode the government, too. It is impossible for a challenger without a great deal of wealth to win a seat in the government. Most people never rule, and many people remain in office for decades. Another problem is dependency. Lack of labor that satisfies one's basic needs foster an atrophy of talents and work skills that must be honed in labor. If a family is not selfsufficient, it is unstable and the same is true for the nation. A system, which is unable to create full employment $(u \cong 0)$, price stability $(\pi \cong 0)$, and balanced its trade $(X=M)$ and budget $(T=G)$ is unnecessary for our societies.

Technology, with its high cost and its contribution to unemployment, has played a significant role in the increasing difficulty of fulfilling basic needs, especially if you are unemployed. Additionally, the overall cost of living keeps rising. We become poorer and poorer every day. Then, the other problem of our free-market system, except unemployment, is inflation, which is mostly a supply-side one, due to our inelastic demands, and the consumers' loans from financial institutions (greediness, profiteering, deception, gluttony, bribery, and corruption). Finally, the production of the nation $(\mathrm{Q})$ must be equal to absorption (E); then, exports will be equal to imports and the government budget in balance. The lack of a sufficient social welfare system, today, puts at risk not only the stability of our democracy, but also the greater good of the ability of citizens to flourish within their nation, which is also losing its sovereignty. The current situation reminds us the Roman Empire at the time of its fall and destruction.

Reliable evidence of any positive impact of privatization on broader growth, efficiency, and welfare is sparse or inexistent. In a democratic society, the perception of "consumers" (citizens and voters) matter more than the politicians' one. Politicians' views and prospects, today, are far away from the citizens' ones; and this is the reason that they try to avoid any referendum. Democracies and democratic values are disappearing from our societies. The future of the citizens and of the new generations will be very difficult. Traditional state ownership, now, plays no economic role in Europe and the list of candidates for continuing privatization is very short. Of course, the pressure from EU, IMF, World Bank, and other international institutions (which are against the indigenous culture, heritage, and freedom of humans) will continue in all countries to sell every asset to the private firms and now, it is the "best time", you can buy public enterprises at a very low market price. Why are these agencies against society? What is their objective? For whom are they working? Who is controlling them?

The unfortunate pro-free-market reformers in Europe aim to continue to privatize all stateowned enterprises and to sell everything that belongs to the tax payers (citizens) to multinational firms (foreigners). The citizens are losing the public wealth; they have no private wealth because the rich foreigners have acquired every private real and financial assets and at the end, they will become homeless in their own country and because of no immigration laws, they will become minorities inside their nation; then, the U.S.A. together 
with the EU will take away their own country and give it to the visitors (illegal immigrants), who have a very high birth rate (and they have become the majority inside the host country). If this is social justice and the philosophy of international laws and institutions are in favor of these crimes against the citizens, against the nations, and against the history, humanity is in trouble! The current financial crisis has proved that privatization needs some moderation. Only governments can act (gradually and moderately) against the business cycle and improve, through public policies and regulation, employment, income, national wealth, and the social welfare of the country. The corrupted private (free-market) financial institutions depend on governments to bail them out.

Finally, privatization proposals in key public services sectors, such as water and electricity, are in many cases strongly opposed by opposition political parties and civil society groups. Usually campaigns involve demonstrations, political means, and strikes by trade unions; sometimes they may become violent, but the state has the police and suppresses the demonstrators. It is possible that national services may sub-contract or out-source functions to private enterprises instead of having a total privatization. Also, a public enterprise may be privatized, with a number of shares $(51 \%)$ in the company being retained by the state. While partial privatization could be an alternative, it is more often a stepping stone to full privatization, but the government is doing this slowly to avoid its political cost. Privatization programs have been undertaken in many countries across the world and in every one in the EU. Stanford (2008) says that "the striking point about the range of case studies presented in Privatization Experiences in the European Union [Kothenburger and Whalley (2006)], however, is that there would seem to be little evidence of any universal truths regarding either the inefficiencies of state ownership, or the benefits of privatization". The first privatization program conducted by transition economies in Central and Eastern Europe after 1989 in the process of instituting a market economy, after the fall of communism, had some rationale. The worst privatization program is the one carried out in developing countries and in high debt EMU member-nations under the pressure by international financial institutions (IMF, World Bank, and EU). The least harmful privatization is the one that is carried out by developed country democratic governments without any pressure from international institutions or the EU, but just to maximize the social welfare of the nation without transferring any power to foreigners or compromising the security and safety of its own citizens.

\section{Acknowledgment}

I would like to acknowledge the assistance provided by Jatinkumar Ahir, Mario Migliori, Brandon Dragone, and Kevin McLaughlin. Also, I am grateful to Rosario Laratta, Aleksandar Lazinica, and Daria Nahtigal for their valuable comments. Financial support (professional travel expenses, submission fees, etc.) was provided by Provost's Office (FRAP Funds and Henry George Funds). The usual disclaimer applies. Then, all remaining errors are mine.

\section{References}

Alexiou, Constantinos (2003), "Reflections on Macroeconomic Policy and European Unemployment after Maastricht: Some Evidence", Spoudai, Vol. 53, No. 1, University of Piraeus, January-March, pp. 13-36. 
Aristotle (1998), Nicomachean Ethics, J.L. Ackrill and J.O. Urmson, ed. David Ross, trans., New York City: Oxford University Press.

Ball, Laurence M. (2009), Money, Banking, and Financial Markets, Worth Publishers, New York, U.S.A.

Becker, Peter (2007), "Privatizing Public Enterprises in the European Union - The Impact of European Integration on European Water Markets", SWP Stiftung Wissenschaft und Politik, Research Unit EU Integration, German Institute for International and Security Affairs, Berlin, December, pp. 1-20.

Bhaskar, V. and Mushtaq Khan (1995), "Privatization and Employment: A Study of the Jute Industry in Bangladesh", The American Economic Review, Vol. 85, No. 1, March, pp. 267-273.

Burnes, Bernard, Michael Katsouros, and Trefor Jones (2004), "Privatisation and the European Union: The case of the Public Power Corporation of Greece", The International Journal of Public Sector Management, Vol. 17, No. 1, pp. 65-80.

Drogalis, Christina (2008), "Aristotle and the American Social Welfare State", Trinity, The University of Scranton, Volume 1, No. 2, Spring, pp. 5-20.

Errunza, Vihang R. and Sumon C. Mazumdar (2000), “Privatization: A Theoretical Framework", Social Science Research Network, February, pp. 1-38.

Freixas, Xavier, Philipp Hartmann, and Colin Mayer (eds.) (2008), Handbook of European Financial Markets and Institutions, Oxford: Oxford University Press.

Kallianiotis (2011a), "The Financial and Public Policy of Greece as a Member of the Economic and Monetary Union", Unpublished manuscript, University of Scranton, July, pages 36 .

Kallianiotis, I.N. (2011b), “Is the Imposed Global 'Laissez-faire' Socio-economic System Responsible for the Latest Financial Crisis?", Journal of Business and Economics, Volume 2, No. 5, 2011, pp. 325-353.

Kallianiotis, I.N. (2011c), "The Latest 'Planned' Financial Crisis, which Caused the First Depression of the 21 ${ }^{\text {st }}$ Century was a Moral and Political Crisis", Unpublished manuscript, University of Scranton, August, pages 155.

Kallianiotis, I.N. (2011d), "What has caused the Depreciation of the U.S. Dollar?", Unpublished manuscript, University of Scranton, October, pages 15.

Kallianiotis, I.N. (2011e), "Privatization and its Significance on European Financial Markets and its Consequence on Social Welfare", Unpublished manuscript, University of Scranton, September, pages 90.

Kallianiotis, I.N. (2010a), "Were the Current Bear Market and the Recession Predictable?", International Journal of Applied Business and Economic Research, Vol. 8, No. 1, June 2010, pp. 37-64.

Kallianiotis,I.N. (2010b), “The Divine Hellenic Language”, Christian Vivliografia, November 12, pp. 1-4. (http:/ / christianvivliografia.wordpress.com/2010/11/12/).

Kallianiotis, Ioannis N. (2009), “European Privatization and its Effect on Financial Markets and the Economy from a Social Welfare Perspective", International Research Journal of Finance and Economics, Issue 28, June, pp. 66-85. 
Kallianiotis, Ioannis N. (2007), “Global Uncertainty, European Unemployment, and the Waning American Competitive Games", Unpublished manuscript, University of Scranton, December, pages 51.

Kallianiotis, Ioannis N. (2003), AAmerican Business Objective: An Alternative Approach@, The Journal of American Academy of Business, Cambridge, Vol. 3, No. 1 \& 2, September, pp. 197-204.

Kallianiotis, Ioannis N. (2002), ASaving and Investment: The Forecast Function of Interest Rate@, American Business Review, Vol. XX, No. 1, January, pp. 50-58.

Kallianiotis, I.N. and Brandon Dragone (2009), "Privatization and Financial Markets in European Union", in Contemporary Issues of Economic and Financial Integration: A Collection of Empirical Work, Panagiotis Andrikopoulos (editor), Athens Institute for Education and Research, Athens, Greece, pp. 355-370.

Kay, J. and D. Thompson (1986), "Privatization: A Policy in Search of a Rationale", Economic Journal, 96, pp. 18-38.

Kikeri, S., J. Nellis, and M. Shirley (1992), Privatization: The Lesson of Experience, The World Bank, Washington, D.C., U.S.A.

Kothenburger, Hans-Werner Sinn and John Whalley (2006), Privatization in the European Union, (editors), CESifo Seminar Series, MIT Press, Cambridge, MA, U.S.A.

Koutsoyiannis, A. (1981), Modern Microeconomics, Second Edition, The Macmillan Press Ltd, London, U.K.

Layard, P.R.G. and A.A. Walters (1978), Microeconomic Theory, McGraw-Hill, New York, N.Y., U.S.A.

Markusen, Ann (2001), "The Case Against Privatizing National Security", Council on Foreign Relations, Privatization.org.

Morgen, Sandra (2001), “The Agency of Welfare Workers: Negotiating Devolution, Privatization, and the Meaning of Self-sufficiency", American Anthropologist, Vol. 103, Issue 3, pp. 747-762.

Moussis, Nicholas (2003), Guide to European Policies, 9th Edition, European Study Service, Belgium.

Nellis, John (2007), "Privatization: A Summary Assessment", SAIS Review, 27, No. 2, Summer/Fall, pp. 3-29.

Parker, David (1999), "Privatization in the European Union: A Critical Assessment of its Development, rationale and Consequences", Economic and Industrial Democracy, 20 (1), pp. 9-38.

Ross, Stephen, Randolph W. Westerfield, and Jeffrey Jaffe (2008), Corporate Finance, Eighth Edition, McGraw-Hill/Irwin, New York, N.Y., U.S.A.

Sappington, D.E.M. and J.E. Stiglitz (1987), "Privatization, Information and Incentives", Journal of Policy Analysis and Management, 6, pp. 567-582.

Stanford, Jim (2008), "Privatization if Necessary, but not Necessarily Privatization?", Review of Income and Wealth, Series 54, No. 1, March, pp. 1-10.

Stiglitz, Joseph E. (2002), Globalization and its Discontents, W.W. Norton \& Company, New York, U.S.A.

Walter, Ingo and Roy Smith (2000), High Finance in the Euro-Zone, Financial Times/Prentice Hall, an imprint of Pearson Education, London, England. 
Willner, Johann (2003), “ Public Ownership and Privatisation in Finland”, CESifo Privatisation Experiences in the EU, Munich, Germany, pp. 1-26.

Wortzel, H. and L. Wortzel (1989), "Privatization: Not the only Answer", World Development, pp. 633-641. 


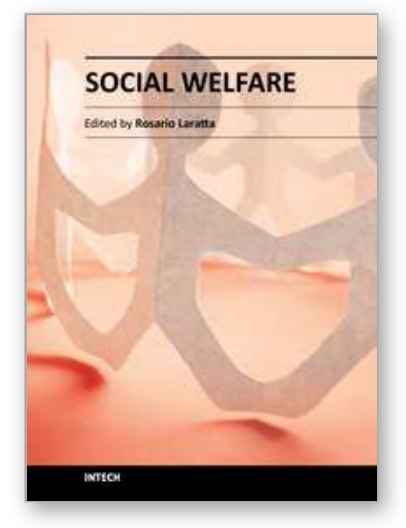

\author{
Social Welfare \\ Edited by Dr. Rosario Laratta
}

ISBN 978-953-51-0208-3

Hard cover, 216 pages

Publisher InTech

Published online 07, March, 2012

Published in print edition March, 2012

"Social Welfare" offers, for the first time, a wide-ranging, internationally-focused selection of cutting-edge work from leading academics. Its interdisciplinary approach and comparative perspective promote examination of the most pressing social welfare issues of the day. The book aims to clarify some of the ambiguity around the term, discuss the pros and cons of privatization, present a range of social welfare paradoxes and innovations, and establish a clear set of economic frameworks with which to understand the conditions under which the change in social welfare can be obtained.

\title{
How to reference
}

In order to correctly reference this scholarly work, feel free to copy and paste the following:

Ioannis N. Kallianiotis (2012). Privatization and Financial Markets in European Union: A Social Welfare Perspective, Social Welfare, Dr. Rosario Laratta (Ed.), ISBN: 978-953-51-0208-3, InTech, Available from: http://www.intechopen.com/books/social-welfare/privatization-and-financial-markets-in-european-union-asocial-welfare-prespective

\section{INTECH}

open science | open minds

\section{InTech Europe}

University Campus STeP Ri

Slavka Krautzeka 83/A

51000 Rijeka, Croatia

Phone: +385 (51) 770447

Fax: +385 (51) 686166

www.intechopen.com

\section{InTech China}

Unit 405, Office Block, Hotel Equatorial Shanghai

No.65, Yan An Road (West), Shanghai, 200040, China

中国上海市延安西路65号上海国际贵都大饭店办公楼405单元

Phone: +86-21-62489820

Fax: +86-21-62489821 
(C) 2012 The Author(s). Licensee IntechOpen. This is an open access article distributed under the terms of the Creative Commons Attribution 3.0 License, which permits unrestricted use, distribution, and reproduction in any medium, provided the original work is properly cited. 